\title{
Report of the workshop on chemical pollution and
}

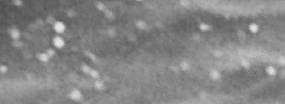

cecaceans

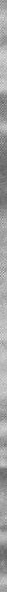

$\frac{3}{63} 5$

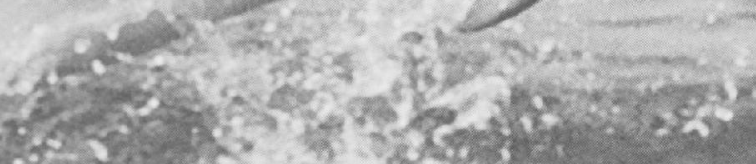

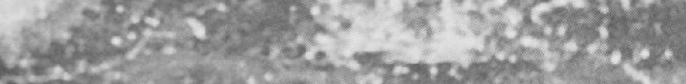

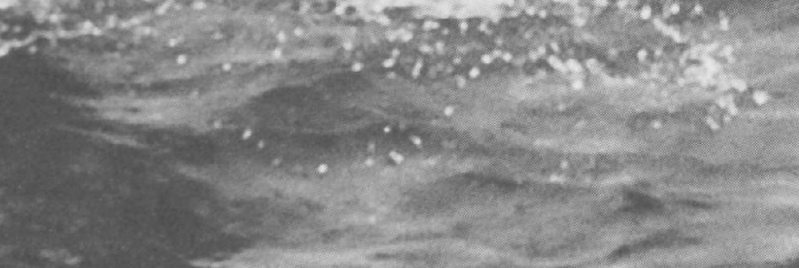

(and
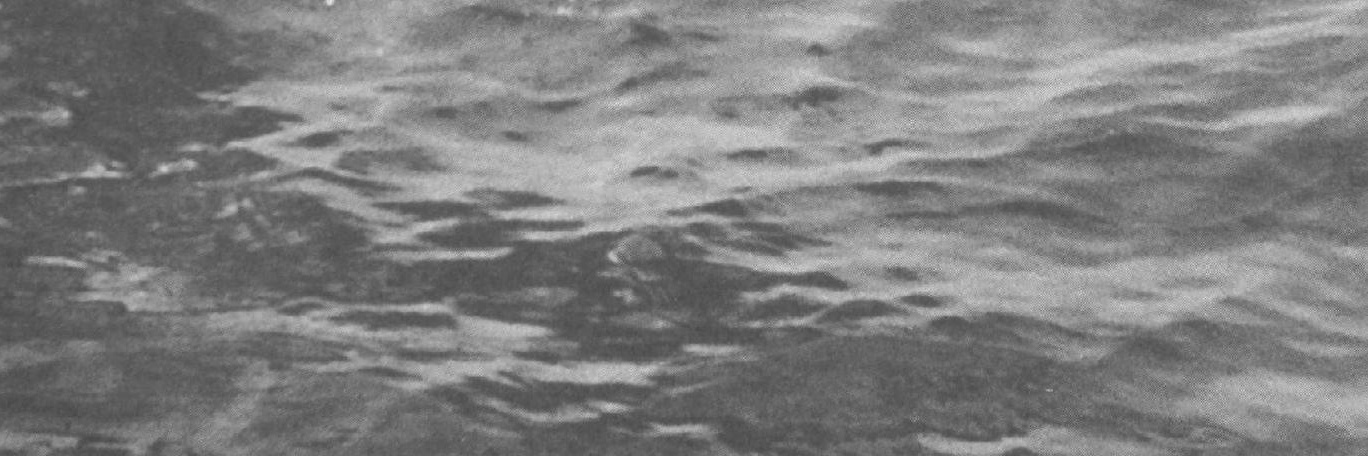
Photograph courtesy of Jaume Forcada 


\title{
Report of the workshop on chemical pollution and cetaceans
}

\author{
Edited by P.J.H. Reijnders, G.P. Donovan, A. Aguilar and A. Buørge
}

\section{INTRODUCTION (including arrangements for Workshop)}

The Workshop was held from 27-29 March 1995 in Bergen, Norway, under the Chairmanship of Peter Reijnders.

Bjørge welcomed the participants to Bergen and summarised the practical arrangements for the Workshop. The list of participants is given in Annex A. Participants acting as rapporteurs and assisting with the Report included Aguilar, Bjørge, Boon, Donovan, Reijnders, Simmonds and Stein. Final editing was carried out by Reijnders, Donovan, Aguilar and Bjørge, including updating before inclusion in this volume.

Donovan thanked the Norwegian Government and the Environmental Investigation Agency Charitable Trust for their financial support, welcomed the participants on behalf of the IWC and described the background to the Workshop.

In 1993 the Commission had stated that the Scientific Committee should

'give priority to research on the effects of environmental changes on cetaceans in order to provide the best scientific advice for the Commission to determine appropriate response strategies to these new challenges' (IWC, 1994a).

At the 1994 Scientific Committee meeting (IWC, 1995a), the Committee had examined this question further and had identified a number of areas that would need to be addressed including: (1) global warming; (2) ozone depletion; (3) pollution; (4) direct (intentional and incidental mortality) effects of fisheries and indirect (ecological ramifications) effects of fisheries; (5) noise; and (6) other human activities (e.g. tourism, coastal developments). Implicit in this is the question of the synergistic and cumulative effects of all of these factors.

The Committee had noted that it was not feasible to address all these topics simultaneously; this would be a longer-term iterative project. Given this, it agreed that initially two specialised Workshops should be held, one relating to chemical pollutants and cetaceans, and the other on the potential ecological effects on cetaceans of climate change and ozone depletion. The latter Workshop was held in 1996 (IWC, 1997) after the publication of the Report of the Intergovernmental Panel on Climate Change (IPCC, 1996). A draft agenda for the present Workshop was drawn up and a Steering Group comprising Reijnders, Bjørge, Aguilar and Stein worked throughout the intervening period to organise the Workshop and ensure that a broad range of expertise was available.

The Scientific Committee (IWC, 1994b) had drawn the Commission's attention to the fact that environmental threats affect all species of cetaceans, not only those subject to direct capture. In fact, the most vulnerable species to such threats might well be those species that are already reduced in numbers, i.e. those for which the Revised Management Procedure would set zero catch limits even if it were applied (Donovan, 1995). It stressed that the IWC may have to contemplate response strategies outside the direct management of whaling 
operations if it wishes any identified threats to be alleviated. This may include local measures in terms of habitat protection or much wider considerations concerning pollutants and greenhouse gas emissions.

Reijnders thanked the participants for their acceptance of the invitation to attend the Workshop and emphasised that the objective of the Workshop was to carry out a full multi-disciplinary assessment of the significance of chemical contaminants for cetaceans.

Relevant documents submitted to the 1994 Scientific Committee meeting were distributed to participants along with those submitted to the Workshop. The list of documents is given as Annex C.

\section{ADOPTION OF AGENDA}

The Agenda adopted is given as Annex B. It was noted that it was important to recognise those biological differences between odontocetes and mysticetes that might affect their susceptibility to certain chemical pollutants. It was also agreed that the Workshop did not have the expertise necessary to discuss the effects of oil spills and oil pollution on cetaceans. However, it draws this subject to the attention of the Scientific Committee as one that warrants consideration in the future (e.g. see review in SC/46/O 8, SC/46/O 14 and Item 5.7). A glossary of terms used and abbreviations included in this Report is given in Annex $D$.

\section{KEYNOTE PRESENTATIONS}

This section contains summaries by the keynote speakers of their presentations and a summary of the comments made by the 'opponent'. Important points arising from general discussions of these presentations are dealt with under the relevant Agenda Items. Readers are referred to the literature cited in the keynote papers for details of references in this section.

\subsection{Individual variation in contaminant levels}

Aguilar presented a review of factors affecting variability of persistent pollutant levels in cetaceans (SC/M95/P6 ${ }^{1}$ ).

(1) Diet is significant because many pollutants are concentrated through food webs. This explains most interspecific differences in pollutant levels and it may also contribute to variation among populations of the same species or even among different components of the same population when diet is subject to age-related or sex-related variations.

(2) The effect of body size is complex. Excretion rate and activity of detoxifying enzymes decrease as body weight increases, processes which tend towards higher pollutant concentrations in larger animals. By contrast, a high metabolic rate - which is inversely correlated to body size - is associated with high pollutant concentrations. These opposite effects usually result in higher residue levels in smaller individuals.

(3) Body composition affects the contribution of each body compartment to the overall pollutant load. Therefore, the body load of lipophilic pollutants will strongly depend on the relative mass of blubber, a variable that can show a threefold variation among cetacean species or, in scasonal feeders, among individuals.

(4) Nutritiv' 'condition also affects the dynamics of lipophilic pollutants. Lipid mobilisation results in an increase in residue levels, in lipid as well as other tissues and blood. However, this variation is not as large as a purely concentrative model would suggest

1 A revised version of this paper is published in this volume. 
because of the enhancement of detoxification processes following a rise in tissue pollutant concentrations.

(5) Disease affects pollutant levels in different ways: impoverishing nutritive condition; altering normal physiological functions; and depressing reproduction and therefore reducing reproductive transfer in females. The combined result of these processes is usually an increase in pollutant levels and a redistribution in tissues of diseased individuals.

(6) The concentrations of most lipophilic pollutants and several trace elements increase with age in males because input exceeds the ability of the organism to excrete these compounds. Variable proportions of the pollutant load are transferred to offspring during gestation and lactation, for which reason tissue concentrations in adult females increase more slowly, stabilise or decrease, thus producing lower residue levels in adult females than in adult males. However, because not all compounds are transferred at the same rate, their relative abundance varies with age and sex. Intensity of reproductive transfer is also associated with the reproductive traits of the species, particularly the length of lactation. For most trace elements these differences between males and females may not be apparent or may even be reversed, with concentrations in females being higher than those in males.

The significance of these factors of variation should be taken into account when designing sampling programmes, comparing sample groups or evaluating toxicological impact.

Skåre (opponent) re-emphasised the need to take into account biological factors when interpreting pollutant levels. She presented data on $\Sigma$ DDT, $\Sigma$ PCB and $\Sigma$ Chlordane for different mammal species from the northern North Atlantic and Arctic regions. These showed a heterogeneous distribution of residue levels among species, with higher values in polar bears and harbour porpoises. This variation was attributed to differences in diet and other biological traits. Patterns of variation of the relative abundance of the various compounds among species and age-related trends in harbour porpoises were discussed. She concluded that the effort devoted in recent years to improving analytical ability should now focus on improving sampling techniques and identifying sources of variability (e.g. nutritional status, tissue location) - aspects that have been frequently neglected in the past.

\subsection{Xenobiotics and metabolism}

Brouwer presented a review of metabolisation of organochlorines in different mammal species with particular reference to the MFO (Mixed Function Oxidase) system (SC/M95/P8 ${ }^{1}$ ).

He noted that persistent induction of biotransformation enzymes may have the following consequences:

(a) increased oxidative stress to the organs/cells experiencing it;

(b) enhanced formation of bioactive metabolites;

(c) increased elimination of endogenous substrates, such as vitamins and hormones;

(d) increased formation of mutagenic, relative intermediates from other xenobiotics, such as PAHs present in the same exposure matrix.

With regard to the formation of bioactive metabolites, he described the metabolism of PCBs and reached a number of conclusions.

(1) Several PCB congeners are readily metabolised to hydroxylated-PCB derivatives. Seals and cetaceans are able to metabolise $\mathrm{PCB}$ congeners with adjacent $\mathrm{H}$ atoms at the ortho, meta position, in combination with at most one ortho chlorine atom.

1 A revised version of this paper is published in this volume. 
(2) There is a clear correlation between EROD (ethoxyresorufin-O-deethylase) induction and metabolism of PCBs (e.g. 3,3',4,4'-TeCB [OH-PCB-77] as model congener) indicating an important role for cytochrome $\mathrm{P} 450-1 \mathrm{~A} 1 / 2$ as a catalyst.

(3) Although in general there is a good correlation between EROD induction and OH-PCB-77 formation, there are some exceptions: (i) fish and fish-eating birds show a low OH-PCB-77 metabolite formation capacity even though EROD is considerably induced, in contrast to liver microsomes from harbour porpoises and harbour seals which do show a considerable potency of OH-PCB formation; (ii) the pattern of $\mathrm{OH}$-metabolites formed from PCB-77 may differ with different species.

(4) High levels of OH-PCB metabolites have been shown to accumulate in the late foetal and early neonatal rats born to mothers perinatally exposed to Arochlor 1254, or PCB-77 (Morse et al., 1995).

OH-PCBs show a metabolic-specific range of bioactivities, including: $T_{4}$-binding competition on TTR; inhibition of type 1-deiodinase; uncoupling of mitochondrial respiration; oestrogen receptor binding; Ah-receptor binding (rat liver cytosol); IC inhibition (Hepa1c1c7); embryo mortality (chick, experimental); EROD induction (Hepalc1c7).

The high levels of foetal accumulation of OH-PCBs may, therefore, be particularly relevant for the observed developmental neurotoxic and reproductive effects in laboratory animals and may thus also pose a risk for adverse developmental effects in wildlife species.

There is a high risk of synergistic effects on the depletion of thyroid hormone and vitamin A by complex mixture exposures, since these mixtures contain parent compound inducing CYP-1A1/2, metabolisable PCB congeners and inducers of UDP-GT isozymes (both 3-MC and $\mathrm{Pb}$-types) that enhance hepatic elimination of thyroxine and vitamin $\mathrm{A}$ derivatives. Studies with several fish-eating birds (cormorants, eider ducks, common terns) and harbour seals have shown reductions in plasma retinol and thyroid hormones associated with EROD inductions and PCB dietary intake levels. The observed PCB-dependent changes in biochemical parameters suggest that they can be useful as biomarkers in wildlife species.

In addition to the possible adverse effects associated with persistent CYP-1Al/2 induction, this parameter itself is nowadays frequently used as a biomarker for exposure, along with assays for CYP-1 A activity, in particular the de-ethylation of ethoxyresorufin (EROD). A close correlation has been shown between CYP-1A content and EROD activity in the liver, and non-ortho/mono-ortho PCB content in the blubber of white whales ${ }^{1}$ Delphinapterus leucas (White et al., 1994). This is a clear correlation between toxic chemical exposure and a biological effect known to be central to the mechanisms involved in diverse forms of chemical toxicity, as summarised above.

Moore (opponent) reported that recent techniques are available to determine CYP- $1 \mathrm{Al} / 2$ protein in situ by immunohistochemical studies (SC/M95/P2). In these studies it was observed that there is also a considerable expression of CYP- $1 \mathrm{Al} / 2$ protein in dermal endothelial cells.

Correlations between this protein content and hepatic and blubber contaminant load suggest that flux of inducing compounds is complex, greater in females than males and probably affected by other compounds in addition to those measured. Determining the significance of these observations against standards is critical for interpretation of CYP-1A/EROD data in dermal biopsy samples.

\footnotetext{
I The accepted IWC common name for this species is the white whale. II is also often referred to as the beluga, belukha or beluga whale.
} 
The latter observations pave the way for the development of immunohistochemical biomarkers of CYP-1Al/2, using relatively small pieces of dermal tissue, which can be collected in a non-invasive way.

\subsection{Cancer in cetaceans, a potential biomarker of environmental contamination}

Martineau presented an overview (SC/M95/P10 $)$ of cancer cases that have been observed in the small (ca 500 animals) population of white whales found inhabiting the St Lawrence Estuary (SLB) in Quebec, Canada, over a 12 year period, 1983-1994. A total of 175 white whales was reported stranded on the shoreline, of which 73 carcasses were examined. Of these, 14 were affected by a malignant tumour (cancer). This represents $40 \%$ of the 35 cancer cases reported worldwide in cetaceans (although this figure is difficult to interpret directly as it is only in this population that rigorous post-mortems are routinely carried out). The annual incidence rate (AIR) of cancer in that population (a minimum of 233/100,000 and a more realistic figure closer to $750 / 100,000$ ) is much higher than that reported for any other population of cetaceans and is similar to that of man and hospitalised domestic animals. More specifically, the AIR of small intestinal cancers (minimum 67/100,000) is much higher than that observed in all animals and man, except sheep in certain parts of the world where an environmental carcinogen is believed to be aetiologically related to this condition. Considering: (1) the demonstrated exposure of SLB to PAHs of industrial origin; (2) the contamination of sediments of the SLB habitat by PAH; and (3) that among odontocetes, this is the only species that feeds predominantly on bottom invertebrates, Martineau suggested that these compounds should be included in any list of possible causes for the high rate of cancers observed in that population.

Clausen (opponent) drew attention to the fact that one should be cautious in comparing AIR values between species because of likely differences in confounding factors.

\subsection{Epidemiology/epizootics and contaminants}

Kennedy presented an overview of the morbillivirus epizootics that had occurred in aquatic mammals in recent years (SC/M95/P5 ${ }^{1}$ ). Morbillivirus infections were unknown in these species until thousands of Baikal seals (Phoca sibirica) died as a result of morbillivirus infection in Lake Baikal in 1987 (Grachev et al., 1989). Approximately 18,000 harbour seals (Phoca vitulina) and a few hundred grey seals (Halichoerus grypus) died as a result of morbillivirus infection in northwestern Europe in 1988 (Kennedy et al., 1988b; Osterhaus and Vedder, 1988; Dietz et al., 1989) and a similar infection killed thousands of striped dolphins (Stenella coeruleoalba) in the Mediterranean Sea in 1990-92 (Aguilar and Raga, 1993). Morbillivirus infection has been shown to be the cause of death of bottlenose dolphins (Tursiops truncatus) in the Gulf of Mexico in 1993-94 (Lipscomb et al., 1994a). Recent studies have established morbillivirus infection as the cause of a major epizootic among bottlenose dolphins along the eastern seaboard of the United States in 1987-88 (Lipscomb et al., 1994b). A previous investigation had implicated brevetoxin as the cause of the die-off (Geraci, 1989).

Clinical signs and lesions in the affected cetacean populations were generally similar to those of morbilliviral diseases such as canine distemper and rinderpest in terrestrial mammals (Kennedy et al., 1988b; 1989; Domingo et al., 1990; 1992). Immunosuppression as a direct result of viral damage to lymphoid tissues was the likely cause of the many secondary bacterial, fungal and protozoal infections seen in morbillivirus-infected animals (Kennedy et al., 1988a; b; Domingo et al., 1992; Lipscomb et al., 1994a; b). Large lysosomal inclusions, apparently not directly caused by morbillivirus infection, were seen in

I A revised version of this paper is published in this volume. 
hepatocytes of a high proportion of striped dolphins during the Mediterranean epizootic (Kennedy et al., 1993).

Comparative genomic analysis and reactivity patterns to monoclonal antibodies, indicate that a strain of canine distemper virus was responsible for the morbillivirus epizootic in Lake Baikal seals (Osterhaus et al., 1989) whereas a newly recognised virus (phocine distemper virus; PDV) caused the European pinniped epizootic (Cosby et al., 1988; Blixenkrone-Moller et al., 1992; Curran et al., 1992). Similar studies indicate that another newly recognised virus, distinct from PDV, was the cause of the epizootic among striped dolphins in the Mediterranean Sea (Visser et al., 1993; Blixenkrone-Moller et al., 1994). This virus is similar but not identical to that isolated from morbillivirus-infected harbour porpoises in northwestern Europe (Kennedy et al., 1988b; Visser et al., 1993). The relationship of the virus or viruses that infected bottlenose dolphins along the eastern coast of the United States in 1987-88 and in the Gulf of Mexico in 1993-94 to the other known morbilliviruses has not been established.

There is evidence that organochlorine contaminants have biological effects, including alterations of in vitro and in vivo indices of immune function in pinnipeds (De Swart et al., 1994; Ross et al., 1995), and it has been suggested that these substances contributed to the mortality of morbillivirus-infected marine mammals. However, such an effect on mortality could not be demonstrated in a study by Harder et al. (1992). Furthermore, morbilliviruses are highly virulent pathogens frequently producing high mortality in susceptible populations and epizootics in terrestrial animals pre-date anthropogenic contaminants. At this stage it is unclear whether contaminants had a role in morbillivirus epizootics in marine mammals. On the other hand, no explanation has been found for the unusually high concentrations of organochlorines found in tissues of striped dolphins during the 1990-92 epizootic in the Mediterranean Sea (Kannan et al., 1993; Aguilar and Borrell, 1994). Likewise, there is no explanation for the occurrence of the hepatocytic lysosomal inclusions in a high proportion of these animals (Kennedy et al., 1993). The possibility that contaminants may have increased the susceptibility of cetaceans to morbillivirus infection, or had an aetiological role in the hepatocytic damage cannot therefore be excluded.

Simmonds (opponent) made reference to the fact that although several large die-offs had been reported in pinnipeds before the recent morbillivirus epizootics (Dietz et al., 1989), mass mortality was an apparently new phenomenon in cetacean populations. He suggested that although morbillivirus infection was the primary cause of these epizootics, they should be regarded as multifactorial events (Eis, 1989). With the possible exception of the Lake Baikal epizootic, all the recent morbillivirus epizootics had been adjacent to heavily industrialised and, therefore, polluted coasts. Some of these events had been associated with relatively high tissue contaminant concentrations (Dietz et al., 1989; Kannan et al.. 1993: Aguilar and Borrell, 1994). There was some indication that seal mortality was apparently lower in some relatively unpolluted areas (Hall et al., 1992). He noted that PCBs had been demonstrated to have immunosuppressive effects in laboratory animals and suggested that the hypothesis that morbillivirus epizootics have been exacerbated by contaminants will probably not be proven because of the difficulty in establishing simple cause and effect relationships for many environmental issues.

During the discussion it was agreed that morbilliviruses were capable of causing high mortality in susceptible (i.e. previously unexposed) populations and were the primary cause of the recent epizootics. However, the possibility of PCB and other contaminants playing a significant role in the mass mortalities of striped dolphins in the Mediterranean and other epizootics cannot be excluded because of the immunosuppressive capacity of such compounds, the uniquely high concentrations of organochlorines in the tissues of these animals and the occurrence of lysosomal inclusions in hepatocytes (see Item 4.1.2.6). 


\subsection{Significance and potential of biomarkers in marine mammal toxicology}

Peakall (SC/M95/P91) presented a review of biomarkers. These were defined (Peakall and Walker, 1994) as a biological response to a chemical or chemicals that give a measure of exposure and sometimes, also of toxic effect'. While the term 'biological response' is broad, it is usually taken to be any response up to the organisation level of the intact animal, although there has been an emphasis on biochemical and physiological effects.

There are two main difficulties with using biomarkers in marine mammals.

(1) The difficulty in collecting suitable samples. Non-destructive collection is desirable both on ethical and scientific grounds. Samples must be fresh and stranded animals, even if alive, may not be representative (see Item 5.3.1).

(2) The lack of experimental work on cetaceans that would allow the establishment of cause-and-effect relationships between biomarkers and chemicals. There is one study on bottlenose dolphins. which shows in vitro effects on immune function related to contaminants (Lahvis et al., 1993; 1995). More extensive data are available on pinnipeds which show effects on vitamin A, thyroid and immune function in harbour seals fed fish from contaminated areas (Brouwer et al., 1989; De Swart et al., 1994; Ross et al., 1995). However, it must be pointed out that pinnipeds are not closely related to cetaceans and therefore the observed cause-and-effect relationship in seals may be different in cetaceans.

He summarised the limited data available on biomarkers in cetaceans.

(1) Formation of DNA adducts. The presence of benzo(a)pyrene adducts has been demonstrated by Shugart et al. (1990) in the St Lawrence white whale population (a polluted area) but they are absent from Arctic specimens (low or less polluted areas). However, no difference in the total number of polyaromatic hydrocarbon (PAH) adducts with DNA was found between animals from these areas (Ray et al., 1991). These studies were carried out on brain tissue, but it was pointed out that skin measurements are also possible.

(2) Induction of Mixed Function Oxidase (MFOs). MFO induction has been demonstrated in cetaceans and, in some cases, it has been correlated with PCB concentrations (Watanabe et al., 1989; White et al., 1994). While the liver is the main target organ, skin biopsies have also been successfully used (Fossi et al., 1992).

(3) Plasma hormone levels. Some studies have been made on plasma hormone levels and a rather weak correlation found between testosterone and DDE (Subramanian et al., 1987).

(4) Immune responses. Detailed studies are underway for the bottlenose dolphins (Lahvis et al., 1993; 1995) and the white whale. With regard to the latter, the background studies in the Arctic have been completed but studies on animals from the St Lawrence population have not yet been carried out (Béland, pers. comm.).

Peakall and Stein (opponent) suggested that hazard assessment could be aided by biomarker data since this gives information on effects rather than merely documenting residue levels. As an ideal, they considered that cetaceans in the open ocean should be physiologically normal, i.e. that human activities should not result in their physiological functions being outside normal limits. The advantages of using physiological normality as a criterion are that it is:

(i) independent of the pollutants involved and thus avoids the problems of mixtures and unknown compounds;

1 A revised version of this paper is published in this volume. 
(ii) philosophically defensible - although it accepts the presence of some level of pollutants (analytical chemistry is too good for zero to be an objective) the levels are such that the physiological function of animals living in the area can be considered normal.

The disadvantages are that we need:

(i) to be able to define physiological normality and, because zero concentrations of pollutants do not exist, this means examining physiological parameters along gradients of pollution;

(ii) to be able to do a comprehensive battery of tests to be confident that physiology is normal and this battery of tests must cover all the major classes of pollutants.

\section{EFFECTS OF CHEMICAL POLLUTION ON CETACEANS}

This section of the Report considers the significance of pollutants to cetaceans with respect to both direct and indirect effects. Effects may be apparent at the molecular level, in an individual or up to the level of the ecosystem (Fig. 1).

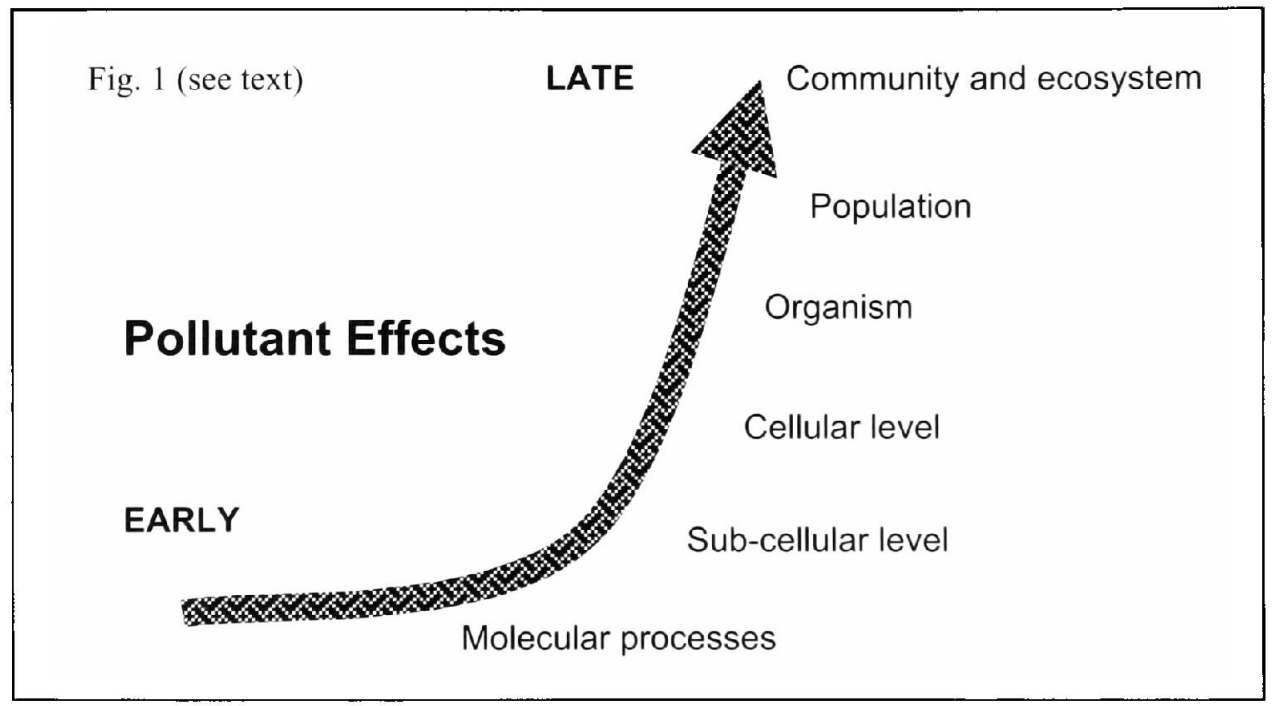

\subsection{Direct effects}

\section{J.I Lethal effects}

There is no indication in the literature of any acute chemical poisoning events (i.e. resulting in rapid death) affecting cetaceans. It was noted, however, that the detailed necropsies that could identify such events are rarely conducted on stranded animals; indeed in such an event, corpses might well not be recovered. Although, Koeman et al. (1971) reported that seals had been acutely poisoned by an accidental discharge of mercury-contaminated disinfectant, most cetaceans (apart from some river dolphins) live far from the point sources of pollution and thus a similar situation is unlikely.

\subsubsection{Sub-lethal effects}

The major chemical threat to cetaceans is through the continuous uptake of persistent lipophilic contaminants through the food chain; for more water soluble organic compounds and trace elements, uptake through water may also be significant. This, over time, may induce sub-lethal effects or, exceptionally, lead to the death of the animal. 
4.1.2.1 DISEASES

Of course, animals suffered from diseases long before the advent of organochlorines and other pollutants. However, the ability of organochlorines (OCs) and other toxic chemicals to cause immunosuppression, secondary diseases and tumours, has also been demonstrated in many laboratory, domestic and free living animals that have been experimentally or accidentally intoxicated with them. They may also by themselves cause morphological changes that are relatively consistent among various animal species. For instance, squamous metaplasia of certain glands, mucous metaplasia of gastric glands, gastric erosions, hepatic lesions and lysis of the adrenal cortex have all been observed after accidental and experimental chronic intoxication.

Although high levels of tissular OCs have been found in a number of cetacean populations, only in a few instances have in-depth pathological and toxicological analyses been performed concurrently. As noted under Item 3.3, the small population of white whales, highly contaminated with OCs, that inhabits the St Lawrence Estuary has been studied over a 12 year period. Only by comparing this population with a 'clean' population has it been possible to demonstrate lesions and bacterial and viral infections consistent with $\mathrm{OC}$ chronic toxicity. In order to investigate whether similar patterns of pathological changes exist in contaminated populations of other cetacean species, the Workshop recommends that other cetacean species that are currently the object of toxicological analysis also be examined with regard to detailed pathology.

A range of pathological changes have been associated with contaminants in other species and these may provide some guidance in the examination of cetaceans. The Workshop noted that in order to investigate any potential relationship between contaminant levels and disease in cetaceans, a long term programme is required, with detailed pathology being combined with consideration of chemical burdens.

A priority list of pathological items to consider is given in Annex E. More detailed instructions for cetacean autopsies have recently been produced (e.g. Kuiken and García Hartmann, 1993; Law, 1994) but may not always be practical in the field. The establishment of a histological collection of normal tissue, might be helpful in the preparation of pathological diagnosis.

The presence of pox-like and other external skin lesions (e.g. Thompson and Hammond, 1992) and their potential relationship to pollutants has been noted in cetaceans and might be monitored as part of other studies.

\subsubsection{REPRODUCTION AND EARLY DEVELOPMENT}

A large number of the man-made chemicals that have been released into the environment, as well as a few natural ones, have the potential to disrupt the endocrine system of animals, including humans (SC/M95/P4). Among these are the persistent, bioaccumulative, organohalogen $(\mathrm{OH})$ compounds that include some pesticides, fungicides, herbicides, industrial chemicals, other synthetic products and some metals.

Studies in terrestrial mammals, reptiles, birds and humans (reviewed in SC/M95/P4) have led to a hypothesis that persistent halogenated compounds can disrupt endocrine function. Evidence has come from studies of chemical residues, steroidal receptor number and function, enzyme induction, plasma steroid concentration, retinoid and thyroid hormones, reproductive micro- and macro-anatomy, reproductive physiology, behaviour and populations.

These effects were generally observed in offspring and were the result of hormonally-responsive tissues being affected during development. For many organochlorines there is no natural barrier to the brain or the womb. The determination of sexual development may be affected in the womb, during the period of time between 
conception and the point when sex-related tissue differentiation normally begins. How far into gestation this normally occurs in cetacean species is unknown. The levels of hormone involved in this differentiation are extremely low - even 'minute' changes in concentrations may, therefore, affect sexual development.

A worldwide reduction in human sperm count has been reported (e.g. Auger et al., 1995) and it has been hypothesised that this is linked to environmental factors, specifically exposure to oestrogen-like compounds in utero and in the early postnatal period. Similarly, sperm quality and mobility are declining for apparently similar reasons (Auger et al., 1995). It was noted that cetaceans (like humans) would be exposed over relatively long periods of time to low doses of endocrine-disrupting chemicals; it is possible, therefore that their early development and reproductive capability may be affected.

There are few published data for cetaceans that allow testing of the hypothesis that there are comparable effects in odontocetes and/or mysticetes. True hermaphroditism in cetaceans (e.g. white whales - De Guise et al., 1994a) is rare but pseudohermaphroditism has been reported in a number of species (e.g. bowhead whales - Koski et al., 1993; fin whales Bannister, 1962; sperm whales - Anon., 1960; striped dolphins - Nishiwaki, 1953). However, it should be noted that whenever endocrine disrupting chemicals have been sought in cetacean tissue they have been found. Effective doses in other mammals including humans are often extremely low; concentration levels in the blubber of some marine mammals exceed those. Odontocetes, especially males, have a higher blubber burden of suspect compounds than mysticetes from the same geographic region (O'Shea and Brownell, 1994). However, many large mysticetes undergo an extended annual non-feeding migration to their tropical or sub-tropical breeding areas. It has been suggested that their annual exposure to chemicals released during consumption of fat reserves during migration may therefore give an increased flux and exposure to persistent chemicals for adults, foetuses and sucklings (SC/M95/P4).

The Workshop considered whether priority species/areas could be identified to facilitate the examination of questions relating to pollutants and reproduction for cetaceans. Where possible, studies of bycaught, stranded and harvested animals should include interdisciplinary projects to analyse molecular, endocrine, enzymatic, histological and gross morphological indices designed to test the hypothesis that accumulation of complex mixtures of organohalogens disrupts normal reproductive form and function in odontocetes and mysticetes.

The Workshop stressed the need to learn more about the differentiation and development of cmbryos, foetuses and early postnatal to prepubertal whales and the dynamics of contaminant transfer to the offspring via gestation and milk. The Workshop recommends that such studies be developed. They should focus either on the analysis of data from bycaught animals in one area with a great range of exposure, or data from a single species in both relatively clean and contaminated areas, carefully measuring other possible confounding variables (e.g. food supply, density-dependent effects on reproduction).

The Workshop noted that measurement technology has already been established in the field of early development and endocrine disruption with laboratory animals. It recommends that samples be collected from neonatal and/or juvenile cetaceans (and other marine mammals) as part of a designed study to develop protocols in order to:

(i) assily for thyroid hormone, vitamin $\mathrm{A}$ and steroid hormone levels in blood plasma;

(ii) assay brain and liver samples for thyroid hormones and vitamin $A$;

(iii) assay oestrogen receptor levels in accompanying ovaries, brain and liver;

(iv) measure glial fibrillary acidic protein (marker of glial cells) and synaptophysins (marker of neuronal development) in various brain regions; 
(v) analyse CYP-1A induction in appropriate organs.

In addition, the level of persistent organic contaminants in cetacean blubber and milk and hydrolysable metabolites in blood and brain should be analysed. The Workshop recommends that the accumulation of bioactive phenolic PCB metabolites in late gestational foetuses and neonates be further investigated in relation to potential developmental neurotoxic and reproductive effects. It also recommends that detailed pathological analysis of gonads, ano-genital axis and other determinants of sexual development be carried out.

The Scientific Committee's attention is drawn to a Workshop held in April 1995 by the US Environmental Protection Agency to develop research strategies for endocrine disrupters in the environment (Kavlock et al., 1996).

It was also noted that functional changes are not always tied to histological changes and that, even within populations of the same species, individual variation in susceptibility is apparent (Langston, 1990). The uterine stenosis and occlusions and other major pathological changes reported from some seal populations (e.g. those in the Baltic and the Wadden Sea; Helle, 1980; Stede and Stede, 1990; Olsson et al., 1994) have not been reported in any cetaceans, despite the fact that, for example, relatively large numbers of harbour porpoises in the North Sea region have been examined. The opportunities for investigations on bycaught cetaceans in other regions were also noted.

An analysis of a long time series of data on Barents Sea harp seal ovaries revealed changes in both the age of maturity and pregnancy rates (Kjellqvist et al., 1995). The availability of suitable material to allow similar analyses for cetacean populations is rare and the difficulties in estimating such trends have been extensively discussed by the Scientific Committee (Cooke, 1985: Kato and Sakuramoto, 1991). However, it was noted that Norwegian scientists are presently analysing data from minke whale ovaries collected over a period of $40+$ years. The results from such studies could be used in further studies to test for correlation with changes in demography and environmental factors, although the difficulty in determining any causal relationships is acknowledged.

\subsubsection{IMMUNE SLPPRESSION}

A relationship between certain chemicals and immune suppression has been well established in laboratory trials and was discussed under Item 3. Ross et al. (1995) and De Swart et al. (1994) have shown impairment of immunological functions in harbour seals fed on fish taken from polluted waters.

Immunosuppression is defined as a measurable alteration in any component(s) of the immune system that is likely to result in increased susceptibility to disease. Alterations in indices of immune function have the potential to act as important biomarkers of exposure to (alterations in in vitro indices but no clinical consequences) or effects of (increased susceptibility to disease) contaminants. A large number of tests are available to measure immune function in domestic and laboratory animals, and in humans. These tests include fluorescent antibody cell sorting (FACS) analysis of immune cells, lymphocyte stimulation tests, cytokine assays, responses to antigens and assessment of natural killer cell activity and phagocytosis.

There are no theoretical reasons why these tests could not be applied to cetaceans but, in practice, only some can be applied immediately; preparation of antibody reagents and workup of tests is required before many of these assays can be used. The Workshop identified the testing of existing antibody markers on cetacean immune cells and preparation of antibodies specific for cetaceans, where required, as priorities for research in this area.

As for other species, interpretation of the results obtained from the application of tests of immune function to cetaceans is likely to present major problems. Potential variables that 
must be considered include sex, age, nutritive state, trace element and vitamin status, individual variation, daily variation, stage of lactation and gestation, and the stress associated with blood sampling. Qualitative and quantitative differences in contaminant burdens may affect the results of assays of immune function and would make it more difficult to establish a dose-response relationship unless there are relatively large changes in immune parameters. Assessment of contaminant burden (tissue concentrations or biomarkers, e.g. CYP-1A) in animals to which tests of immune function were applied, is essential in order to determine cause-effect relationships.

Because of the many confounding factors requiring consideration, establishment of 'normal' values for most assays of immune function would probably be difficult and require a large sample size. A realistic chance of success would only be obtained from the examination of a small number of carefully defined cetacean populations from which this type of sampling is feasible. Examples of these include Arctic and St Lawrence white whales; isolated populations of harbour porpoises along the US coast; and bottlenose dolphin populations along the central west coast of Florida (e.g. Scott et al., 1990; Wells and Scott, 1990). Highly contaminated and relatively uncontaminated individuals are required to enable a comparison of immune function. Although controlled experimental studies would facilitate interpretation of results, such studies on cetaceans are probably impracticable.

In summary, the Workshop agreed that because of the potential importance of tests of immune function in cetaceans, possible difficulties should not delay the development of assays. The adverse effects of organochlorines on immune function and reduced resistance to infectious disease have already been demonstrated in laboratory species. The Workshop recommends that studies to determine reliable markers of immune function in cetaceans are given high priority. The need for increased numbers of detailed necropsies on cetaceans was also emphasised in order to detect infectious or neoplastic diseases that might result from immunosuppression.

The Workshop recommends that priority be given to the development of the following immunological markers:

(1) markers for CD $4 / \mathrm{CD} 8 \mathrm{~T}$-cell surface antigens;

(2) monocyte markers;

(3) B-cell markers;

(4) an in vivo model of grafting lymphocytes from e.g. cetaceans and mice for study of their functioning towards immunological challenges;

(5) further development of in vitro immuno-functional tests using white blood cells from cetaceans;

(6) more general markers that indicate structural components of immune system, such as blood cell counts, histopathology on thymus and lymph nodes, and immune globulins;

(7) markers that indicate susceptibility to infections that are not part of the structural integrity of immune system;

(8) vitamin A levels; and

(9) steroid/thyroid hormone levels.

Work is in progress on immune functions and in vitro exposure assays of immune cells of Arctic white whales that are only lightly contaminated with OCs (De Guise et al., 1996a; b). Results from these studies may provide a unique opportunity to determine a dose-response relationship between alteration of immune functions and $O C s$ in the St Lawrence population, since these whales show a wide range of tissular OC concentrations. Similar work has been initiated on bottlenose dolphins (Lahvis et al., 1993: 1995) and collaboration between the two research groups is planned. 
The Workshop noted that if blood samples are to be used in immunological studies, they must be obtained from living animals (or within a few minutes of death) that have not been subjected to excessive stress.

\subsubsection{CANCER INDUCTION AND MUTAGENIC EIFECTS}

Cancer generally results from a succession of separate injuries to the genome over a long period of time. Therefore, it is a rare event in wildlife and its detection requires the thorough examination of large numbers of individuals over an extended period. As in humans, there may be situations where exposure to specific and potent carcinogenic substances may lead to an unusually high prevalence of tumours. This has been observed in benthic fish feeding in areas contaminated with $\mathrm{PAH} / \mathrm{HAH}$. The high prevalence of cancer in St Lawrence white whales (De Guise et al., 1994b and see Item 3.3) suggests a possible causal relationship through exposure to a carcinogen. The question of genetic susceptibility to cancer was raised; preliminary studies of white whale populations suggest that animals in the St Lawrence Estuary are more closely related to each other than animals within the other populations (Béland, pers. comm.).

However, the very low number of tumours reported from other cetaceans examined over decades, therefore remaining undetected (SC/M95/P10), indicates that cancer may not be a main cause of death for members of this taxa. However, there are numerous histological and molecular markers that precede the development of clear neoplasia. These include induction of cytochrome P4501A, the presence of mutant oncogenes and quantification of DNA adducts. These biomarkers have been used extensively in hazard assessment for chemical exposure in marine organisms and fish in particular (Hugget et al., 1989; McCarthy and Shugart, 1990).

\subsubsection{BEHAVIOUR}

Behavioural toxicology is an area of considerable research involving laboratory animals and a number of studies have shown impacts of contaminants on various aspects of laboratory animal behaviour (Daly et al., 1989; Daly, 1990; 1993). However, it is difficult to assess the relevance of these studies to animals in the wild. The difficulty in measuring behavioural changes in free-ranging cetaceans and attempting to relate this to contaminant levels is apparent. Although such changes cannot be precluded, the Workshop believes that logistical problems mean that this is not a promising area for future work compared with the others it had identified.

\subsubsection{EPIZOOTICS}

During the 1987-1988 North Sea harbour seal morbillivirus epizootic, high mortality rates were observed in the colonies in which pollutant levels were higher (Simmonds et al., 1993). In addition, in the 1990-1992 Mediterranean striped dolphin epizootic, PCB levels were found to be significantly higher in individuals that died than in those sampled before the event or in those that survived (Aguilar and Borrell, 1994). These apparent associations between organochlorine levels and intensity of mortalities have only been observed in these two cases, although no proper analyses to determine the existence of this association were carried out in other epizootics. While a cause-effect relationship cannot be demonstrated (see Item 3.4), the Workshop recommends that further investigations are carried out to elucidate the involvement of pollutants in epizootics, and in particular, in cetacean immune competence (see Item 4.1.2.3). 


\subsection{Indirect effects}

Attention was focused on the main effects of pollutants on fish and the role of fish in pollutant transmission to cetaceans. Fish are excellent vehicles of lipophilic pollutants such as organochlorine compounds. In addition, they are unable to metabolise many of these and thus are carriers of persistent chemicals. Recognised effects of pollutants in fish and other prey consumed by cetaceans include: (i) effects at the molecular level such as genotoxicity, activation of oncogenes, disturbance of molecular regulators, induction of biotransformation enzymes and increased activation of mutagens; (ii) effects at the subcellular and cellular level, such as proliferation of organelles, reduced stability of lysosomes and increased cellular transformations and necrosis; (iii) effects at the tissue (e.g. necroses) or systemic level, such as development of immunosuppression and tumours and impairment of reproduction; (iv) effects at the individual level, such as alterations of metabolism, homeostasis and behaviour, lowered fitness, increased susceptibility to pathogens and overall decrease in lifespan; (v) effects at the population level, such as lowered quality of genetic pool, population susceptibility to disease, depression of recovery rates and increases in mortality rates, all factors leading to a decrease in prey population size. Moreover, they may ultimately also induce changes in the structure of the community or even the ecosystem.

The discussion centred on the different mechanisms by which fish and invertebrate abundance and quality may be reduced by chemical agents. It was agreed that, in the long term, the anomalies observed have the potential for reducing prey population numbers and therefore cetacean food availability. ICES (the International Council for the Exploration of the Sea) has considerable experience and expertise in this field but was unable to send a representative to the Workshop. The Workshop recommends that ICES be approached for an evaluation of the effects of pollutants on the abundance and quality of cetacean prey (mainly crustaceans, cephalopods and fish). It also recommends that the IWC Workshop on climate change should give particular consideration to changes in overall productivity and prey species, and how this might be evaluated through predictive modelling.

\section{RESEARCH IMPLICATIONS}

\subsection{Consideration of synergistic/cumulative effects}

No information on synergistic effects of contaminants in cetaceans was presented at the Workshop and no examples exist in the published literature. However, the Workshop recognised that, although such effects are difficult to identify, they have been documented for some other species (e.g. Friend and Trainer, 1970). The Workshop considered that cumulative effects are more likely to occur in cetaceans.

\subsection{Exotic compounds}

Laboratories tend to routinely analyse concentrations of well-known compounds such as PCBs, DDTs and trace elements. However, information is available about the presence of many other contaminants in the marine environment. Because of the sheer numbers of these contaminants, a set of criteria needs to be developed to select priority compounds with regard to identifying effects on cetaceans. These criteria should include the levels of production, bioaccumulation potency and toxicity of these compounds.

One example considered was the insecticide toxaphene. Although not routinely analysed, it has a similar global production to PCBs and the bioaccumulation from mackerel to cetaceans in the North Sea is at least one order of magnitude (Andersson and Wartanian, 1992; De Boer and Wester, 1993). It is also a class of mutagenic and carcinogenic 
compounds. The transport mechanism is evaporation from the tropics (where it is still produced and used) followed by atmospheric transport and subsequent condensation in polar regions.

Additional examples are tris(4-chlorophenyl)methane and -methanol, compounds of uncertain origin which occur in marine mammals; one possible source is from dye production.

Table 1 presents an overview of three categories of compounds: one that is already being monitored on a routine basis; one that at present can only be analysed by specialised laboratories; and one for which only limited information is available but for which it is suggested that bioassays should be carried out to determine if further action on them should be taken. Laboratories are therefore encouraged to measure these compounds to obtain a more complete picture of contaminants in cetaceans.

One approach to direct the selection of compounds for closer study is to screen on effects first e.g. by toxicological assays. Carcinogenicity, cytochrome P450 induction and sex hormone interference may be suitable criteria for this purpose. The calculation of QSARs (an index of similarity of structure and function) may also work well for chemicals with the same mode of action (e.g. Ah-responsive compounds).

The continuous input of non-bioaccumulative compounds into the marine environment may also present a hazard to marine mammals. An estimate of the exposure to these compounds could be obtained from the analyses of stomach contents (e.g. for PAHs) when bile (which is traditionally analysed) is not available.

In summary, a choice must be made whether to start from a consideration of the concentrations of compounds or from the consideration of effects. In principle, it is preferable to start with screening tests on effects, to be followed by a search for the responsible compounds when an effect is seen. However, immunoassay kits for total PCBs and some pesticides are currently being developed, and they may provide cost-effective analytical screening tools.

Table 1

Priority list of compounds to be tested for in cetaceans.

\begin{tabular}{lll}
\hline Routine & Non-routinc' $^{\prime}$ & Unknown' $^{\prime}$ \\
\hline PCBs & Toxaphene $^{3}$ & TCP/TCPMe \\
DDT/DDD/DDE & Chlordane metabolites & Tetrabrombisphenol \\
$\mathrm{HCB}$ & PBDEs & CPs \\
$\mathrm{HCHs}$ & PCNs & Bromocyclene \\
Dieldrin & PBBs & Nitromusk compounds \\
$\mathrm{PCDDs} / \mathrm{PCDFs}$ & PCTs & \\
$\mathrm{Hg}, \mathrm{Pb}, \mathrm{Zn}, \mathrm{Cd}$ & PCDEs & \\
$\mathrm{Cu}, \mathrm{Se}$ & PCBs metabolites (MSF and OH, blood only) \\
$\mathrm{Chlordanes}$ & PAH-metabolites & \\
& TBT/TPT & \\
& Chlorostyrenes & \\
& Radionuclides (Po-210, Cs-137) & \\
\hline
\end{tabular}

${ }^{1}$ Further information from bioassays is requested. ${ }^{2}$ Including planar CBs. ${ }^{3}$ Based on toxicity data and concentrations found, laboratorics are encouraged to analyse toxaphene on a routine basis. ${ }^{4} \mathrm{An}$ alternative may be determining PAHs in the stomach contents of cetaceans not exclusively feeding on fish.

\subsection{Adequacy of present monitoring}

The main objective for monitoring pollutants in cetaceans is to determine whether levels at which adverse effects occur can be demonstrated, and to use these to infer the health of individuals or populations. This must include an understanding of temporal and geographical 
trends in pollutant levels. Monitoring programmes should be carefully designed to achieve this objective.

Most past monitoring programmes for cetaceans merely measured concentrations of chemicals in tissues. This information alone is insufficient to determine the effects (if any) of pollutants on populations. The Workshop recommends that monitoring of tissue concentrations is accompanied by monitoring of appropriate biomarkers, pathological examinations and evaluation of incidence of alterations in reproductive biology and early development, as well as collection of appropriate biological data.

Given the present lack of knowledge on cause-effect relationships between cetacean health and chemical pollutants, the Workshop recommends that priority is given to carefully defined and designed studies on species and in areas where success is more likely, i.e. populations which are in highly polluted areas that are likely to exhibit adverse affects and those from the same species which are in pristine or relatively unpolluted areas that may be used to infer baseline biological parameters or physiological 'normality'. Potential species/areas include: bottlenose dolphins in areas where longitudinal studies have been established, such as central west Florida, which can be compared to captive animals and to those inhabiting less polluted areas; white whales from the well-studied population in the polluted St Lawrence River and those from other less/low polluted areas in the high Arctic; harbour porpoises from differently contaminated areas on both sides of the North Atlantic.

\subsubsection{Sources of samples}

Tissue samples for pollution studies in cetaceans may originate from three basic sources: (i) strandings; (ii) direct or incidental catches; and (iii) biopsies from free-ranging individuals. Each sample source has advantages and limitations.

Strandings may be divided into single and mass events. In the first case, the analytical results obtained are particularly prone to bias and should be carefully interpreted (see e.g. IWC, 1986). Single stranded cetaceans are likely to have suffered from a disease and, if this has been severe and long term, they are also likely to be in poor nutritional status. The sexand age-composition of stranded individuals will probably not correspond with that of the 'healthy' population. In addition, stranded corpses are usually collected at unknown post-mortem times and some loss of pollutants is likely to have occurred. As discussed under Item 3.1, these variables strongly influence tissue pollutant levels, for which reason stranded individuals are likely to carry abnormal pollutant levels in their tissues. SC/M95/P6 compared pollutant concentrations found in stranded striped dolphins in the Mediterranean with those found in free-ranging, 'healthy' individuals sampled with a biopsy dart and found very different distributions of tissue concentration frequencies between the two sample sets, with more extreme values, both low and high, in the stranded dolphins.

Mass strandings, although devoid of many of these drawbacks, are an occasional and highly unpredictable source of samples.

Direct or incidental catches are good sample sources with all the necessary associated biological data being relatively easy to obtain, but may be limited to a small number of species and geographical regions. In addition, the sex and age composition of the sample may also be biased when compared to the aclual population (e.g. see discussions in IWC, 1989).

Biopsy samples collected 'at distance' from free-ranging, apparently healthy cetaceans, are devoid of most of the above shortcomings but have limitations in the associated biological information that can be obtained. Sex, nutritional status and reproductive condition can be assessed from biopsy samples using various molecular and genetic techniques. However, as yet no techniques for determining age, a significant variable in 
pollution studies are available (Aguilar and Borrell, 1995). The Workshop recommends that research be conducted to determine if it is possible to age individuals from skin or blubber tissue samples. The Workshop noted that IWC/IDCR cruises already undertake biopsy sampling of blue, humpback and right whales on an opportunistic basis. It recommends that, where possible, this be extended to biopsy sampling of small cetaceans. This should be considered for all research carried out under IWC auspices.

SC/M95/P14 presented information on a Japanese Government programme 'Project of Global Environment Monitoring with Fishing Vessel Network', scheduled to cover 1992-96. The authors noted that as part of this, Japanese vessels involved in the JARPA programme in the Antarctic (IWC, 1995a, p.28), as well as those contributed for use as part of the IWC/IDCR Southern Hemisphere assessment cruises (IWC, 1995a, p.33), are collecting samples of air and water for pollutant studies. It was commented that this represented a useful addition to studies in a poorly covered area.

\subsubsection{Biomarkers}

Biomarkers are being developed and used to improve the characterisation of exposure to chemical contaminants in wild populations. This improved characterisation can provide information necessary to link increased exposure to a chemical contaminant to an adverse or deleterious biological effect. However, the use of biomarkers in cetaceans is in its infancy and considerable research is needed to determine dose-response relationships to validate biomarkers, as well as developing appropriate molecular probes (e.g. monoclonal antibodies).

In addition, biomarkers of exposure can be used as an alternative to measurements of concentrations of compounds with the same mechanism of action (e.g. CYP-1A induction for the presence of Ah-responsive compounds).

Initially, at least, priority should be given to biomarkers that have been validated in studies with appropriate surrogate species (e.g. DNA-adducts, MFO induction, measures of immune function). At the second stage the use of other biomarkers should be explored. Samples will need to be collected non-destructively from apparently healthy animals (e.g. biopsy tissue or fluid samples) along relatively well known pollution gradients, and from animals for which as much associated information as possible is available (e.g. sex, age, reproductive status).

The measurement of these biomarkers must be related to the status of the target organ (e.g. MFO induction in skin and the response in the liver). This 'calibration' can be carried out on cetaceans legally taken, incidentally caught or mass stranded. Individuals suspected to be diseased should be avoided to exclude interference of the disease with the biomarker.

As noted above, data for both cetaceans and 'exposure', are needed from non or low-polluted populations to try to establish physiological normality. It is also important that appropriate standardisation and quality assurance controls are established to allow comparison among studies.

\subsubsection{Biological variables}

The Workshop recommends that all available data on each specimen from which material has been taken for pollutant analyses should be properly documented; at least sex, age and nutritional status should be collected whenever possible (SC/M95/P6). Measurement of nutritional status is difficult because reliable condition indices have not been developed for most cetacean species. Blubber thickness is often unreliable and the use of blubber weight and lipid content of the blubber in standardised body locations is recommended. Lipid content is important because, particularly in emaciated individuals, lipid mobilisation may be 
coupled with increased blubber water content. Collection of these biological data is important for the interpretation of the toxicological results. Law (1994) provides an example protocol.

\subsubsection{Pathology examinations}

Necropsies should be carried out by a pathologist preferably with cetacean experience. One suggested protocol for pathological procedures is given in Annex E.

A list of factors to be examined in the context of alterations to reproduction and early development is given under Item 4.1.2.2.

\subsubsection{Specimen banking}

The Workshop recommends that the IWC should encourage and facilitate the standardisation of sampling procedures, storage and collection of associated information among already existing specimen banks and the exchange of relevant information about samples in those banks among institutes carrying out cetacean research.

It also recommends that cell types from various organs should be cultured from cetaceans and made available through agencies such as the American Type Culture Collection. This would facilitate studies of biochemical mechanisms and enable dose-response relationships for various endpoints to be established, for comparison with biopsy material.

Tissue samples obtained from stranded animals, biopsies, legal or incidental catches should be archived, frozen or fixed, as possible. The Workshop recommends that priority be given to establishing genomic DNA libraries and complementary DNA (cDNA) libraries from different organs and information on archived samples be made available to investigators.

Hindrance to the exchange and transfer of tissue or other samples from marine mammals continues to hamper the progress of investigations that otherwise would be possible. Efforts should be made to facilitate the exchange of materials between investigators around the world.

\subsection{Further evaluation of the relationship between toxic burden and impacts}

There are about 100,000 synthetic organic compounds currently in use and more are being produced. If each compound is metabolised to an average of three metabolites, then at least 300,000 compounds could be present in the environment. Compounds for which concern has been expressed include: organohalogens, PAHs, metals, endocrine disrupters and organo-tin and organo-mercury. Measurements of levels of these in the environment and in animals are needed for both parent compounds and metabolites of these chemicals (see Item 5.2).

Differences in residue profiles between prey and predators can be used to alssess metabolism of compounds. The ICES Marine Chemistry Working Group is developing an approach for analysing PCB patterns in prey and preditors and, in this waly, identify compounds that are being metabolised by the predator. The general principle of that approach is given by Reijnders and de Ruiter-Dijkman (1995) and Boon o' (dl. (1992). In the ICES Working Group approach, log-transformed concentrations of a given congener are plotted against congener 15.3, a persistent PCB congener that is not readily metabolised. If a congener is metabolised, the slope of the relationship will be $<1$. By comparing relative ratios of various individual congeners in marine mammals to the relative ratios in a reference prey organism, one can atsess metabolism of congeners without specifically analysing for metabolites.

The hypothesis that cytochrome P450 was responsible for the metabolism of PCBs was confirmed with in vitro studies of harbour seal liver (Murk et al.. 1994). 
Analyses for metabolites should include target organs, storage sites (e.g. blubber and bile) and blood. The relationships among these compartments need to be assessed. There are only a few stable PCB metabolites (Bergman et al., 1994) that are of toxicological concern.

The Workshop noted that in recent years, less research interest appears to have been devoted to metal pollutants in comparison to organochlorines. From the perspective of cetaceans this balance requires redressing somewhat. Some of the relatively small amount of direct evidence with respect to the effect of pollutants is the association of lesions with mercury burden in bottlenose dolphins (Rawson et al., 1993).

The detoxification mechanisms of heavy metals (protein binding and interactions with other elements, such as mercury and selenium) were discussed. The significance of interactions among essential metals and toxic trace elements and, particularly, speciation was noted. The importance of measuring not only total metal levels but also the contribution of the different organic forms as well as concentrations of essential metals was emphasised. It is necessary to determine the physico-chemical form (i.e. speciation) of toxic trace elements in tissues as well as mechanisms of detoxification, with the aim of relating the possible biological effects to the accumulated toxicological active dose. Attention to elements other than cadmium and mercury (those traditionally considered) is warranted. Similarly the potential for differences among subgroups in a population in their ability to detoxify trace elements (e.g. different pilot whale schools at the Faroe Islands - Caurant et al., 1993) requires greater attention. Detoxification mechanisms, including metal binding proteins whose primary function may not be detoxification, should be further elucidated, based on studies of terrestrial mammals and marine invertebrates (e.g. Kagi and Nordberg, 1979; Furness and Rainbow, 1990). Tissues other than the 'traditional' liver and kidney should be examined, because metals may alter the effects of OCs on endocrine functions.

Little information is available on radionuclides and thus the Workshop was unable to evaluate the potential threat posed by this group of pollutants ( $\mathrm{SC} / 46 / \mathrm{O} 8)$. However, it was agreed that they warranted concern (see Item 5.7) and required further investigation.

In terms of adverse health effects related to pollutants, the most sensitive time period is the embryonic and neonatal development stage (see Item 4.1.2.2). Later stages of life may be useful for monitoring the expression of pathological symptoms and signs, such as cancer in adults. In view of the high sensitivity of the early life-stage and the potential long-term consequences of any effects that are induced, the Workshop recommends:

(1) that biological samples from foetal and neonatal cetaceans are collected to obtain measurements of exposure (parent compounds and metabolites) and early biological effects; and

(2) when collecting data through destructive sampling techniques, information from tissues of developing foetuses as well as tissues that are routinely collected through non-destructive techniques should be collected in order to allow the development of models on the potential for foetal exposure when only non-destructive sampling is performed.

\subsection{Risk and hazard assessment techniques}

Risk assessment generally implies some degree of quantification for an adverse biological effect and in cetaceans only the incidence of cancers in white whales (see Item 4.1.2.4) seems able to meet this requirement. For this reason it was agreed that it was only possible to consider hazard assessment with respect to chemical contaminants in cetaceans and that this might be achieved from the perspective of biomarker studies (see Item 5.3.2).

Biomarkers should be measured, in conjunction with analytical chemical data, along likely gradients of pollution, to try to determine the level of exposure at which an adverse effect 
occurs. To achieve this in a reasonable time frame, a small number of appropriate species/populations need to be identified and targeted. It must be recognised that in cetaceans it is difficult to obtain these data and, even when obtained, they must be assessed against a range of non-chemical factors. A suite of biomarkers that have been well validated in other species are needed. Studies focussed on non-destructive sampling should attempt to relate response in biopsy samples to suspected target tissues and determine dose-response relationships. Quality Assurance/Quality Control (QA/QC) procedures should be employed in biomarker studies as well as in analytical determinations.

A major issue that must be addressed is relating biomarker response to detrimental biological effects. It was agreed that studies should focus on species and areas that might be expected to be more likely to enable a linkage to be established between biomarker response and a serious physiological effect as well as the threshold at which this effect occurs. An important caveat is that there is a potential for highly species-specific effects to occur and thus it is not possible to extrapolate among species with a high degree of confidence. It is extremely important that any such studies attempt to elucidate the role of other biological factors (e.g. age, reproductive status) and their influence on biomarker response.

\subsection{Trends in global contamination}

Information on geographical and temporal trends in contaminants contained in SC/M95/P7, SC/M95/P13, Tanabe et al. (1994) and Loganathan and Kannan (1994) were considered. Most information available concerns organochlorines and originates from the Northern Hemisphere. Only limited information is available on heavy metals or from the Southern Hemisphere. There has been a relative increase of PCBs+DDT levels in the tropical belt. Pollutant levels in the water of most rivers and coastal waters in the Northern Hemisphere showed an initial decrease in the late $1970 \mathrm{~s}$, but have generally remained constant since then. In open waters such levels are stable or have increased in recent years. Overall, levels in the Southern Hemisphere have increased in recent years, although they are still lower than in the Northern Hemisphere. Information on cetaceans is limited to short periods of time and certain regions, and in most cases follow these general patterns. However, systematic data on temporal trends in contaminants in cetaceans from the Southem Hemisphere are limited to studies on bottlenose and common dolphins in South Africa (De Kock et al., 1994) and minke whales in the Antarctic (SC/M95/P13).

A confounding factor in assessing temporal trends in heavy metals is their natural occurrence, sometimes at high level sources (e.g. Greenland, the Mediterranean) in marine systems.

As noted under Item 5.2, for many 'exotic' compounds, no information on past or current levels is available.

The Workshop recognised that evaluation of temporal and geographical trends requires careful consideration of recent improvements in analytical techniques and capability. Early samples from some regions may have contained significant amounts of unidentified contaminants that were wrongly assigned, such as the insecticide toxaphene eluting with PCB congeners.

The Workshop recommends that temporal and spatial trends in the concentrations of pollutants should continue to be examined from different species and geagraphical regions.

\subsection{Identification of additional areas of concern}

The Workshop identified a number of subjects of new or future concern: (1) oil pollution; (2) the possible link between chemical pollution and epizootics (see Item 4.1.2.6); (3) marine debris; (4) sewage-related pathogens (Anon., 1993); (5) nutrient related environmental 
alterations (e.g. Geraci et al.. 1989); and (6) radionuclides. Although outside the scope of this meeting, these issues are matters of concern (see SC/46/O 8 and $\mathrm{SC} / 46 / \mathrm{O} 14$ ) and should be addressed by the IWC Scientific Committee and in the deliberations of the forthcoming Workshop on the effects of climate change on cetaceans.

The Workshop draws the attention of the Scientific Committee to the report 'Contaminants and Marine Mimmals' produced by the Scientific Advisory Committee of UNEP's Marine Mammal Action Plan (UNEP, 1991). The objectives of the recommendations in that report partly overlap with those in the present Workshop Report and include: (a) the evaluation of the health status of marine mammal populations in both polluted and less polluted environments; (b) the development of scientific teams to respond to large-scale mortalities of marine mammals and to evaluate the significant causes and contributing factors underlying such events; (c) the application of scientific knowledge to anticipate, mitigate and prevent further ecosystem deterioration.

The Workshop noted that, as part of the follow up to UNCED, a global intergovernmental meeting was held in November 1995 to discuss a programme of action to address worldwide concern over the impact of anthropogenic contaminants on marine wildlife populations and marine ecosystems; the absence of incontrovertible scientific evidence is not seen as an impediment to the development of an action programme. However, further examination of sources and impacts in marine wildlife populations will be imperative for the continued development of global action and to enable commitments (e.g. Agenda 21) to reduce chemical pollutant emissions 'to levels that are not harmful to man or nature' to be quantified.

\section{IMPLICATIONS FOR THE FUTURE WORK OF THE IWC SCIENTIFIC COMMITTEE}

This Workshop represents the initial stage of the IWC Scientific Committee's consideration of the broad issue of the effects of environmental change on cetaceans. The Committee has recognised that the normal expertise available to it was insufficient to address this issue; this is reflected in the large proportion of Invited Participants at the Workshop. The Workshop stressed that the impetus generated by its Report and recommendations should not be lost and the Scientific Committee should consider ways to ensure that this does not happen. One way this could be achieved would be for the Committee to invite scientists with the relevant expertise to its regular meetings and for member nations to include such experts on their national delegations. The holding of a future Workshop or Workshops to review progress should also be considered. A mechanism also needs to be developed to synthesise the results of the various topics included in the overall examination of the effects of environmental change on cetaceans. In the shorter term, for example, a number of matters that require further consideration but were outside the scope of this Workshop are noted under Item 5.7 and, in particular, issues that should be examined at the Workshop to be held on climate change are identified under Item 4.2. The importance of cooperating with other international and regional bodies working on related issues (e.g. ICES, IOC, UNEP and the Oslo and Paris Commissions) is stressed.

The Workshop noted that its work and recommendations are of relevance to a wider audience than the IWC's Scientific Committee. It hoped that the research guidelines and recommendations included will be of value to research groups around the world who are beginning to address questions of cetaceans and chemical pollutants, and to stranding networks who are determining the types of analysis that can be carried out for the animals that they encounter. 
Since its inception, the primary responsibility of the IWC has been the management of whaling. In the light of the discussion of the value of obtaining samples from 'healthy' animals, the Workshop noted that should animals be taken under IWC regulations, relevant samples should be collected (see Item 5.3). It recommends that the Scientific Committee considers making more specific the reference to collection of samples for pollutant analysis in the 'Guidelines for Data Collection and Analysis under the RMP' (IWC, 1995b). Similar samples should be obtained wherever possible from aboriginal subsistence whaling. In addition, the Workshop reiterated the importance of using biopsy techniques to obtain samples from free ranging animals.

While the Workshop believed that all its recommendations are important, it felt that certain specific recommendations should be forwarded by the Scientific Committee to the Commission for more immediate action. In particular those recommendations that will provide results for specific populations and do not need to wait for the completion of the fundamental research for a full, comprehensive analysis of the effect of chemical pollutants on all cetacean species. These are identified under Item 7. The Workshop stresses the need for multidisciplinary focussed programmes of research to be developed and believes that the IWC Scientific Committee should act as a catalyst in this.

\section{RECOMMENDATIONS}

The Workshop recommendations are included in full in Table 2 but do not follow the order in which they appear in the report. They have been grouped from the general to the specific; Recommendation 1 can be said to summarise the findings of the Workshop.

The Workshop believes that there are sufficient data on the adverse effects of pollutants on the health of other marine mammal and terrestrial species to warrant concern for cetaceans. However, the report and its recommendations show that a considerable amount of fundamental research is needed before it will be possible to adequately address the question of the effects of chemical pollutants on all cetaceans.

Notwithstanding the cautionary note that it is often not appropriate to extrapolate from one species to another, it is clear that if any progress is to be made within a reasonable time frame, a multidisciplinary, multinational focussed programme of research is required that concentrates on those species/areas where there is most chance of success. The Scientific Committee (and the Commission) is strongly urged to consider ways to facilitate the development and execution of such research.

Three species are considered particularly suitable: the bottlenose dolphin; the harbour porpoise; and the white whale.

\section{The bottlenose dolphin}

The animals along the coast of central west Florida represent some of the best studied in the world (e.g. Scott et al., 1990). Most of the animals in the Sarasota-Bradenton area have been identified and capture-mark-release techniques have been used since 1970. The animals are thus relatively used to being handled (including the taking of blood samples) and a number of physiological and toxicological studies are underway as noted elsewhere in this report. Associated biological data will therefore often be available for living animals. Local populations are being studied in many parts of the world (e.g. see Würsig and Jefferson, 1990) and thus a 'pollutant concentration gradient' exists; the potential for international cooperation is high. In addition, this species is the most commonly held in captivity (and successfully bred) and thus offers great potential for baseline studies and investigations. 


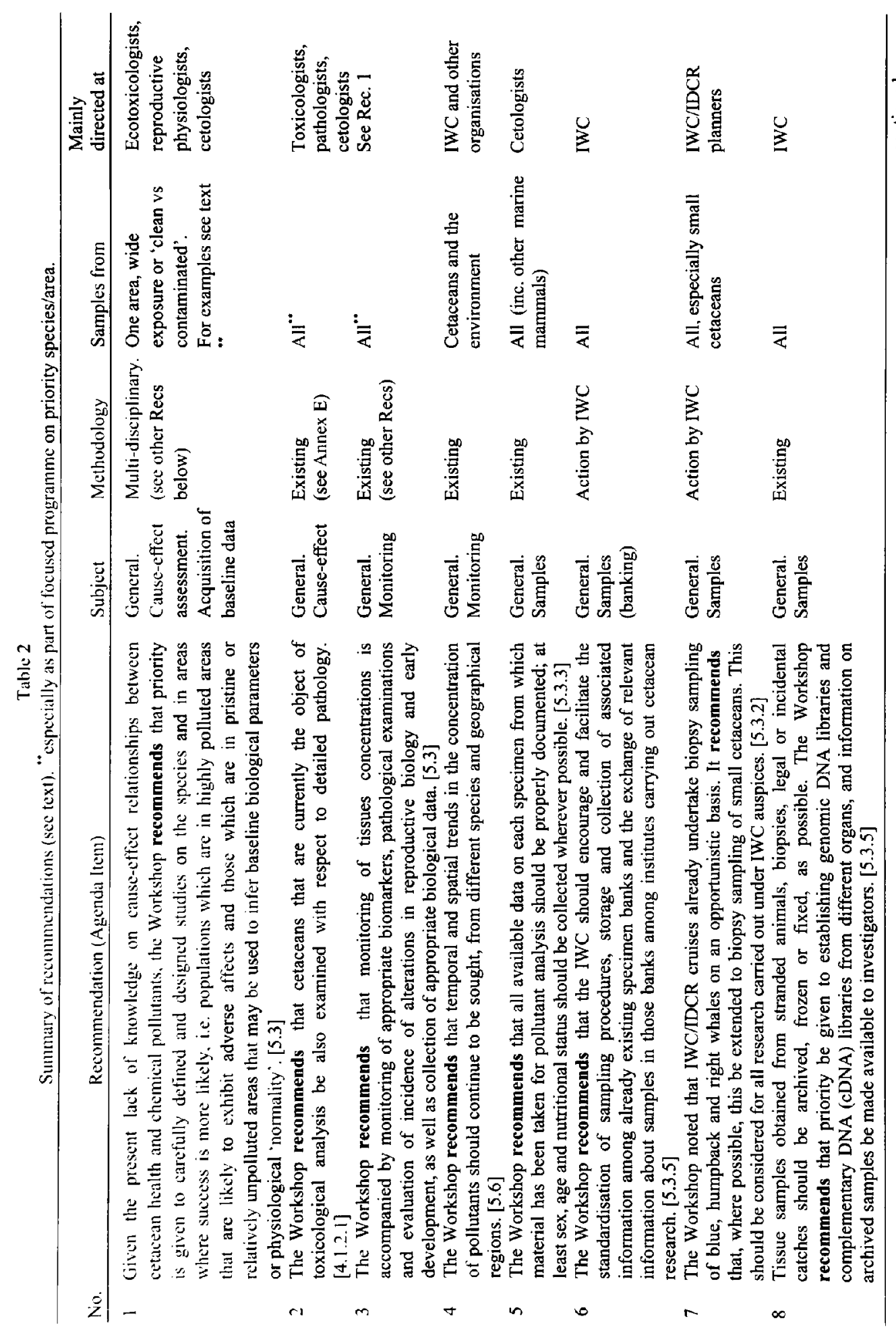




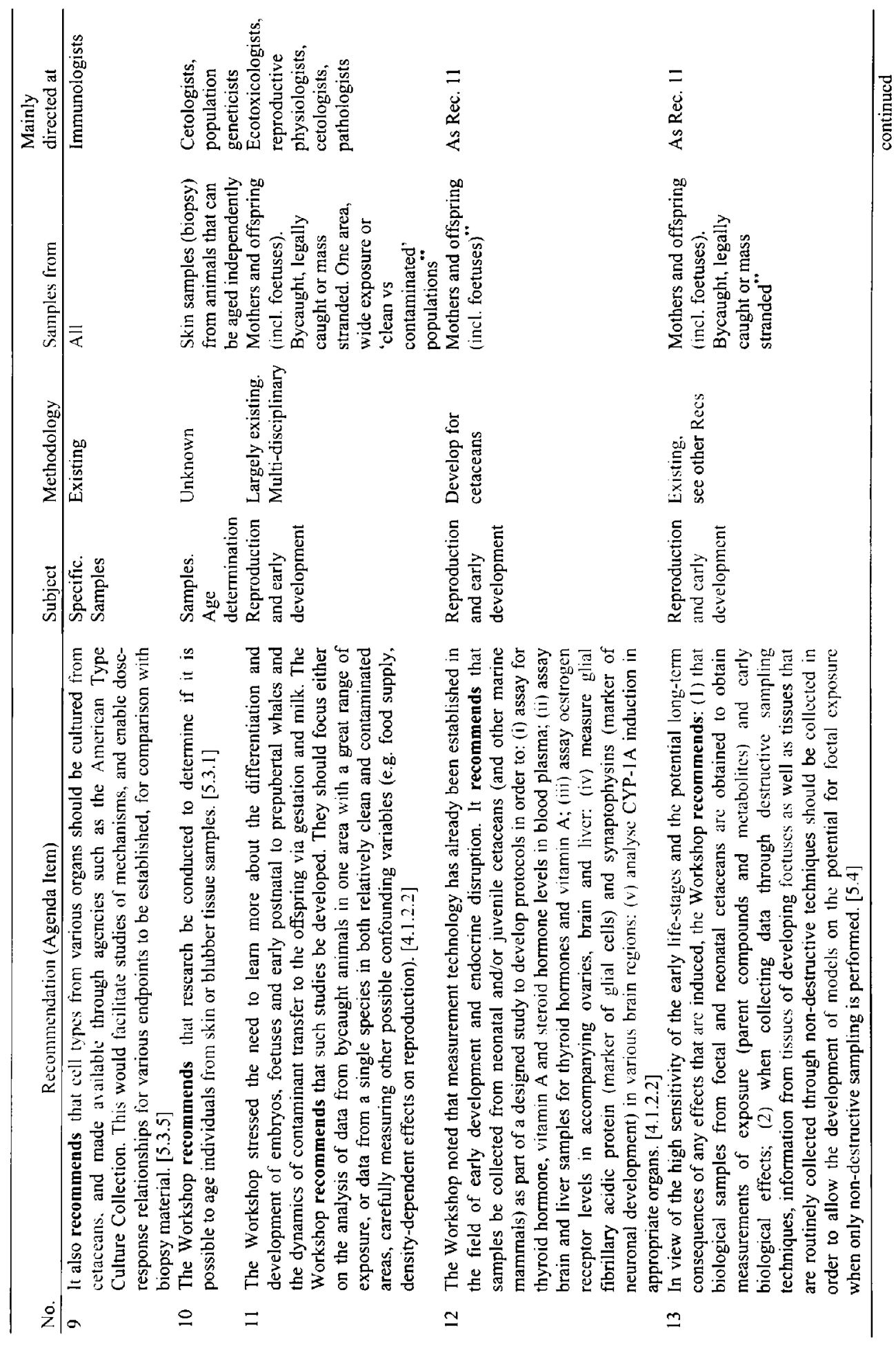




\begin{tabular}{|c|c|c|c|c|c|c|c|c|}
\hline & \begin{tabular}{|l}
$=$ \\
$\dot{y}$ \\
$\dddot{y}$ \\
$y$ \\
$z$
\end{tabular} & 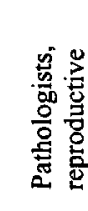 & 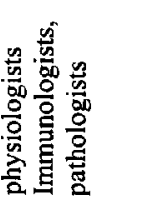 & 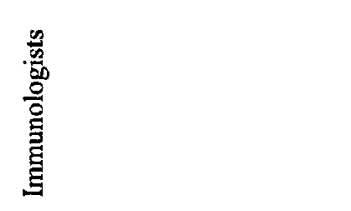 & 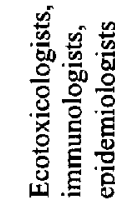 & 惫 & 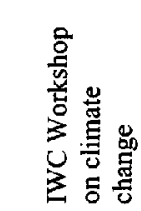 & 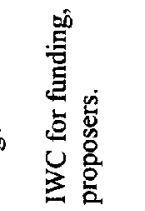 \\
\hline & 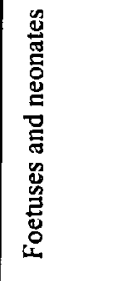 & 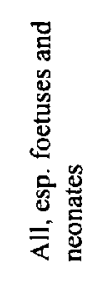 & 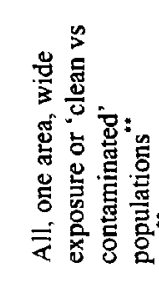 & 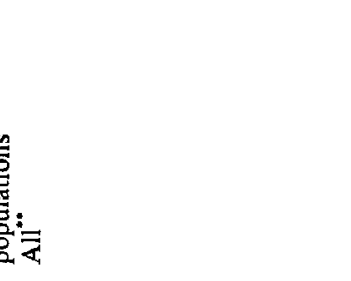 & 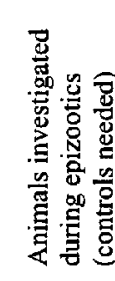 & $\nexists$ & $\Xi ̊$ & 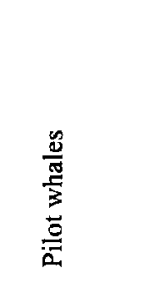 \\
\hline 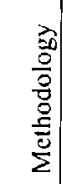 & 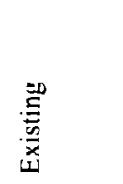 & 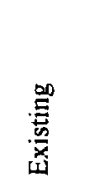 & 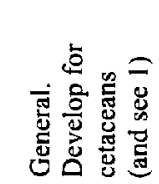 & 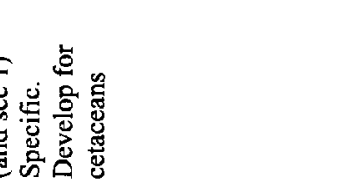 & 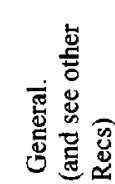 & 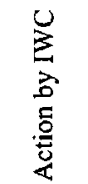 & 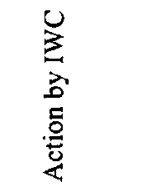 & $\begin{array}{l}\text { 墨 } \\
\text { 离 }\end{array}$ \\
\hline & 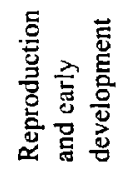 & 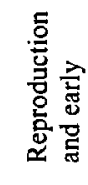 & & 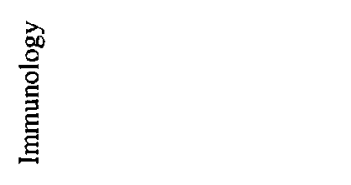 & 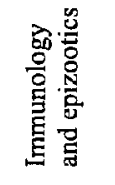 & 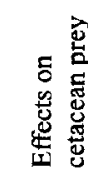 & 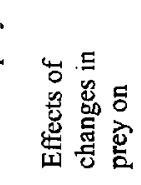 & 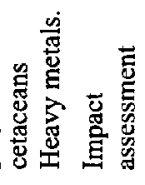 \\
\hline 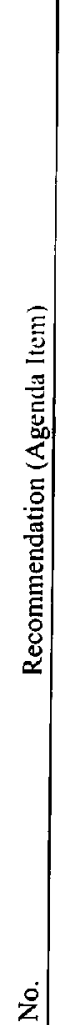 & 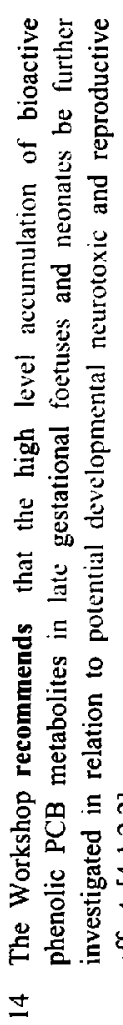 & 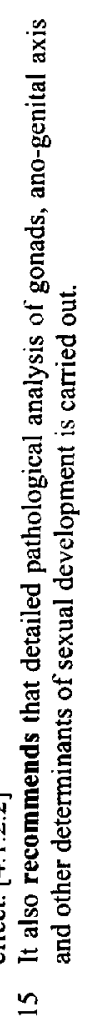 & 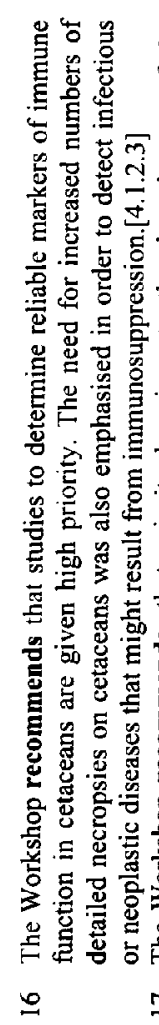 & 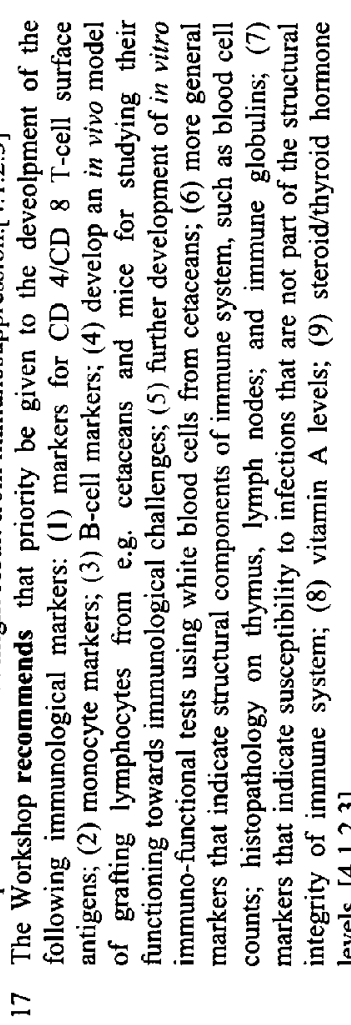 & 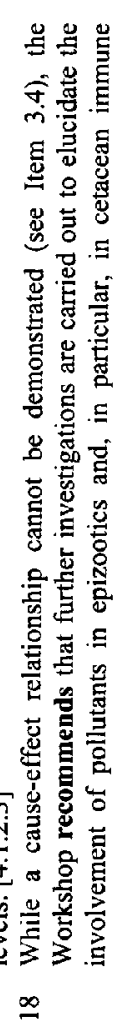 & 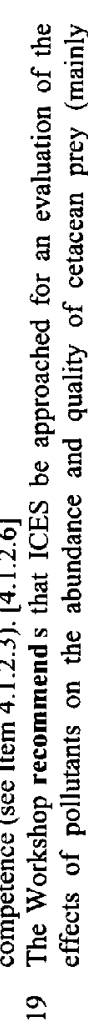 & 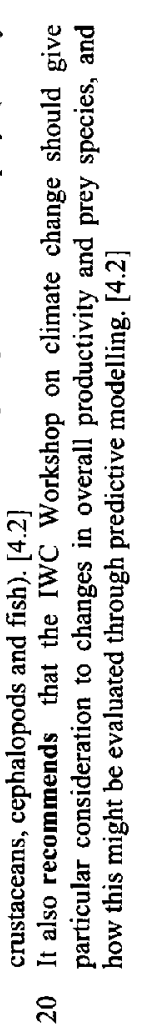 & 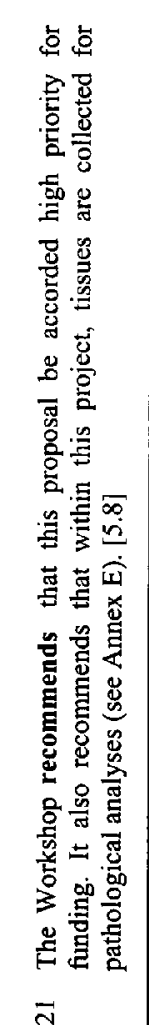 \\
\hline
\end{tabular}




\section{The harbour porpoise}

The harbour porpoise is one of the most susceptible to incidental capture in fishing gear (e.g. Donovan, 1994). Potentially therefore, a large number of relatively unbiased samples can be obtained (although there appears to be some bias towards young animals) across a 'pollutant concentration gradient', for which all the requisite associated biological data can be obtained (e.g. on both sides of the North Atlantic). Aguilar and Borrell (1995) has summarised the work on pollutants carried out on this species to date. Some harbour porpoises are kept in captivity.

\section{The white whale}

As noted throughout the report, the small St Lawrence population is one of the best studied cetacean populations from the perspective of health and pollutants; comparative work with populations from less polluted areas is already underway and could be facilitated by international cooperation (e.g. with Greenland, the Russian Federation and the USA). There are also some animals kept successfully in captivity.

\section{PUblications}

The Report of the Workshop and selected papers will be published in a volume in the IWC special issue series, to be edited by Reijnders, Aguilar and Donovan.

\section{ADOPTION OF REPORT}

The Report was adopted at 18:30 on 29 March 1995. It was not possible in the time available to complete the editorial work necessary to finalise Item 7. The Workshop delegated this responsibility to Reijnders and Donovan, who were also assigned the task of final editing of the Report for consistency, style and references, and production of the glossary. It was noted that the Report remained confidential until after it was posted to Commissioners. The Workshop especially thanked Helen Sharp who typed the Report throughout the long night of 28 March!

\section{REFERENCES}

Aguilar, A. and Borrell, A. 1994. Abnormally high polychlorinated biphenyl levels in striped dolphins (Stenella coerulcoalba) affected by the 1990-1992 Mediterranean epizootic. Sci. Total Environ. 154(2-3):237-47.

Aguilar, A. and Borrell, A. 1995. Pollution and harbour porpoises in the eastern North Atlantic: a review. Rep. int. Whal Commn (special issue 16):231-42.

Aguilar, A. and Raga, J.A. 1993. The striped dolphin epizootic in the Mediterranean Sea. Ambio 22(8):524-8.

Andersson, O. and Wartanian, A. 1992. Levels of polychlorinated camphenes (toxaphene), chlordane compounds and polybrominated diphenyl ethers in seals from Swedish waters. Ambio 21(8):550-2.

Anonymous. 1960. Hermaphrodite sperm whales. Norsk Hvalfangstid. 49(9):433.

Anonymous. 1993. Assessment of potential impact of the MWRA outfall on endangered species. Biological assessment prepared pursuant to Section 7 of the Endangered Species Act. United States Environmental Protection Agency, Region 1, JFK Federal Bldg. Boston MA 02203. 206pp. [Plus Appendices].

Auger, J., Kunstmann, J.M., Czyglik, F. and Jouannet, P. 1995. Decline in semen quality among fertile men in Paris during the past 20 years. New England J. Med. 332:281-5.

Bannister, J.L. 1962. An intersexual fin whale Balacneptera physalus (L.) from South Georgia. Proc. Zool. Soc. Lond. 141:811-22.

Bergman, $\AA$., Klasson-Wehler, E. and Kuroki, H. 1994. Selective retention of hydroxilated PCB metabolites in blood. Lmiron. Health Perspect. 102:464-9. 
Blixenkrone-Moller, M., Sharma, B., Versanyi, T.M., Hu, A., Norrby, E. and Kovamees, J. 1992. Sequence analysis of the genes encoding the nucleocapsid protein and phosphoprotein $(P)$ of phocid distemper virus and editing of the $\mathrm{P}$ gene transcript. J. Gen. Vir. 73:885-93.

Blixenkrone-Moller, M., Bolt, G., Gottschalck, E. and Kenter, M. 1994. Comparative analysis of the gene encoding the nucleocapsid protein of dolphin morbillivirus reveals its distant evolutionary relationship to measles virus and ruminant morbilliviruses. J. Gen. Vir. 75:2829-34.

Boon, J.P., Van Arnhem, E., Jansen, S., Kannan, N., Petrick, G., Schultz, D., Duinker, J.C., Reijnders, P.J.H. and Goksøyr, A. 1992. The toxicokinetics of PCBs in marine mammals with special reference to possible interactions of individual congeners with the cytochrome P450-dependent monooxygenase system: an overview. pp. 119-59. In: C.H. Walker and D.R. Livingstone (eds.) Persistant Pollutants in Marine Ecosystems. SET AC Special Publications Series. 1st. Edn. Pergamon Press, Oxford.

Brouwer, A., Reijnders, P.J.H. and Koeman, J.H. 1989. Polychlorinated biphenyl (PCB)-contaminated fish induces vitamin $\mathrm{A}$ and thyroid hormone deficiency in the common seal (Phoca vitulina). Aquat. Toxicol. 15:99-106.

Caurant, F., Amiard-Triquet, C. and Amiard, J.C. 1993. Factors influencing the accumulation of metals in pilot whales (Globicephala melas) off the Faroe Islands. Rep. int. Whal. Commn (special issue 14):369-90.

Cooke, J.G. 1985. Has the age at sexual maturity of Southern Hemisphere minke whales declined? Rep. int. Whal. Commn 35:335-40.

Cosby, S.L., McQuaid, S., Duffy, N., Lyons, C., Rima, B.K., Allan, G.M., McCulloch, S.J., Kennedy, S., Smyth, J.A., McNeilly, F., Craig, C. and Orvell, C. 1988. Characterization of a seal morbillivirus. Nature, Lond. 336:115-6.

Curran, M.D., O'Loan, D., Kennedy, S. and Rima, B.K. 1992. Molecular characterisation of phocine distemper virus: gene order and sequence of the gene encoding the attachment (H) protein. J. Gen. Vir. 73:1189-94.

Daly, H.B. 1990. Reward reductions found more aversive by rats fed environmentally contaminated salmon. Neurotoxicol. Teratol, 13:449-53.

Daly, H.B. 1993. Laboratory rat experiments show consumption of Lake Ontario salmon causes behavioural changes: support for wildlife and human research results. J. Gt Lakes Res. 19(4):784-8.

Daly, H.B., Heatzler, D.R. and Sargent, D.M. 1989. Ingestion of environmentally contaminated Lake Ontario salmon by laboratory rats increased avoidance of unpredictable aversive nonreward and mild electric shocks. Behav. Neurosci. 103(6):1356-65.

De Boer, J. and Wester, P.G. 1993. Determination of toxaphene in human milk from Nicaragua and in fish and marine mammals from the northwestern Atlantic and the North Sea. Chemosphere 27:1879-90.

De Guise, S., Lagace, A. and Béland, P. 1994a. True hermaphroditism in a St. Lawrence beluga whale (Delphinapterus leucas). J. Wildl. Dis. 30(2):287-90.

De Guise, S., Lagacé, A. and Béland, P. 1994b. Tumors in St. Lawrence beluga whales (Delphinapterus leucas). Vet. Pathol. 31(4):444-9.

De Guise, S., Bernier, J., Defresue, M.M., Martineau, D., Béland, P. and Fournier, M. 1996a. Immune functions in beluga whales ( $D$. leucas): evaluation of mitogen-induced blastic transformation of lymphocytes from peripheral blood, spleen and thymus. Vet. Immunol. Immunopathol. 50(1-2):117-26.

De Guise, S., Bernier, J., Martineau, D., Béland, P. and Fournier, M. 1996. Effects of in vitro exposure of beluga whale lymphocytes to heavy metals. Environ. Toxicol. Chem. 15(8):1357-64.

De Kock, A.C., Best, P.B., Cockcroft, V. and Nosma, C. 1994. Persistent organochlorine residues in small cetaceans from the east and west coasts of Southern Africa. Sci. Total Environ. 154(2-3):153-62.

De Swart, R.L., Ross, P.S., Vedder, L.J., Timmerman, H.H., Heisterkamp, S.H., Van Loveren, H., Vos, J.G., Reijnders, P.J.H. and Osterhaus, A.D.M.E. 1994. Impairment of immune function in harbour seals ( $P$ hoca vitulina) feeding on fish from polluted waters. Ambio 23:155-9.

Dietz, R., Heide-Jorgensen, M.-P. and Härkönen, T. 1989. Mass deaths of harbor seals (Phoca vitulina) in Europe. Ambio 18(5):258-64.

Domingo, M., Ferrer, L., Pulmarola, M. and Marco, A. 1990. Morbillivirus in dolphins. Nature, Lond. 348:21.

Domingo, M., Visa, J., Pumarola, M., Marco, A.J., Ferrer, L., Rabanal, R. and Kennedy, S. 1992. Pathologic and immunocytochemical studies of morbillivirus infection in striped dolphins (Stenella coeruleoalba). Vet. Pathol. 29:1-10.

Donovan, G.P. 1994. Developments on issues relating to the incidental catches of cetaceans since 1992 and the UNCED conference. Rep. int. Whal. Commn (special issue 15):609-14.

Donovan, G.P. 1995. The International Whaling Commission and the Revised Management Procedure. pp. 4-10. In: E. Hallenstvedt and G. Blichfeldt (eds.) Additional Essays on Whales and Man. High North Alliance, Lofoten, Norway.

Eis, D. 1989 . Simplification in the etiology of recent seal deaths. Ambio 18(2):144. 
Fossi, M.C., Marsili, L., Leonzio, C., Notarbartolo-di-Sciara, G., Zanardelli, M. and Focardi, S. 1992. The use of non-destructive biomarkers in Mediterranean cetaccans - preliminary data on MFO activity in skin biopsy. Mar. Pollut. Bull. 24(9):459-61.

Friend, M. and Trainer, D.O. 1970. Polychlorinated biphenyl: interaction with duck hepatitis virus. Science 170:1314-6.

Furness, R.W. and Rainbow, P.S. (eds.). 1990. Heavy Metals in the Marine Environment. CRC Press.

Geraci, J.R. 1989. Clinical investigation of the 1987-88 mass mortality of bottlenose dolphins along the US central and south Atlantic coast. Final report to National Marine Fisheries Service and US Navy Office of Naval Research, and Marine Mammal Commission, Guelph, Ontario, Canada. 63pp.

Geraci, J.R., Anderson, D.M., Timperi, R.J., St. Aubin, D.J., Early, G.A., Prescott, J.H. and Mayo, C.A. 1989. Humpback whales (Megaptera novaeangliae) fatally poisoned by dinoflagellate toxin. Can. J. Fish. Aquat. Sci. 46(11):1895-8.

Grachev, M.A., Kumarev, V.P., Mamaev, L.V., Zorin, V.L., Baranova, L.V., Denikina, N.N., Belikov, S.I., Petrov, E.A., Kolesnik, V.S., Kolesnik, R.S., Dorofeev, V.M., Beim, A.M., Kudelin, V.N., Nagieva, F.G. and Sidorov, V.N. 1989. Distemper virus in Baikal seals. Nature. Lond. 338:209-10.

Hall, A.J., Law, R.J., Wells, D.E., Harwood, J., Ross, H., Kennedy, S., Allchin, C.R., Campbell, L.A. and Pomeroy, P.P. 1992. Organochlorine levels in common seals (Phoca vitulina) which were victims and survivors of the 1988 phocine distemper epizootic. Sci. Total Environ. 115:145-62.

Harder, T.C., Willhaus, T., Leibold, W. and Leiss, B. 1992. Investigations on cause and outcome of phocine distemper infection in harbour seals (Phoca vitulina) exposed to polychlorinated biphenyls. J. Vet. Med. Sci. 39:19-31.

Helle, E. 1980. Lowered reproductive capacity in female ringed seals (Pusa hispida) in the Bothnian Bay, northem Baltic Sea, with special reference to uterine occlusions. Ann. Zool. Fenn. 17:147-58.

Hugget, R.J., Kimerle, R.A., Mehrle, D.M. and Bergman, H.L. 1989. Biomarkers: Physiological and Histological Markers on Anthropogenic Stress. Lewis, Boca Raton, Florida. 346pp.

Intergovernmental Panel on Climate Change. 1996. The Science of Climate Change: Summary for Policymakers and Technical Summary of the Working Group I Report. Cambridge University Press, Cambridge. 56pp.

International Whaling Commission. 1986. Report of the Scientific Committee, Annex K. Report of the working group on ways of maximising information from strandings. Rep. int. Whal. Conmm 36:119-32.

International Whaling Commission. 1989. Report of the Special Meeting of the Scientific Committee to consider the Japanese research permit (feasibility study). Rep. int. Whal. Commn 39:159-66.

International Whaling Commission. 1994a. Chairman's Report of the Forty-Fifth Annual Meeting. Appendix 12. Resolution on research on the environment and whale stocks. Rep. int. Whal. Commn $4+35$.

International Whaling Commission. 1994b. Report of the Scientific Committee. Rep. int. Whal. Conmn 44:41-201.

International Whaling Commission. 1995a. Report of the Scientific Committee. Rep. int. Whal. Commn 45:53-103

International Whaling Commission. 1995b. Report of the Scientific Committee. Annex O. Guidelines for data collection and analysis under the Revised Management Scheme (RMS) other than those required as direct input for the Catch Limit Algorithm (CLA). Rep. int. Whal Commm 45:215-7.

International Whaling Commission. 1997. Report of the International Whaling Commission Workshop on Climate Change and Cetaceans. Rep. int. Whal Commm 47:293-319.

Kagi, J.H.R. and Nordberg, M. 1979. Metallothionein. Expertemria Supplement 34 [Proceedings of the First International Meeting on Metallothionein and Other Low Molecular Weight Metal-Binding Proteins].

Kannan, K., Tanabe, S., Borrell, A., Aguilar, A., Focardi, S. and Tatsukawa, R. 1993. Isomer-specific analysis and toxic evaluation of polychlorinated biphenyls in striped dolphins affected by an epizootic in the western Mediterranean Sea. Arch. Environ. Contum. Toxic ol. 25(2):227-33.

Kato, H. and Sakuramoto, K. 1991. Age at sexual maturity of southern minke whales: a review and some additional analyses. Rep. int. Whal. Commn 41:331-7.

Kavlock, R.J., Daston, G.P., DeRoss, C., Fenner-Crisp, P., Gray, L.E., Kaatari, S., Lucier, G., Luster, M., Mae, M.J., Maczka, C., Miller, R., Moore, J., Rolland, R., Scorr, G., Sheehan. D.M., Sinks, T. and Tilson, H.A. 1996. Researcl needs for the risk asscssment of health and environmental effects of endocrine disrupters: a report of the US EPA-sponsored workshop. Emirom. Health Perspect, 104 (suppl. 4):715-40)

Kennedy, S., Smyth. J.A.. Cush, P.F.. McCuliough, S.J., Allan. G.M. and McQuaid, S. 1988a. Viral distemper now found in porpoises. Nature 336(6194):21.

Kennedy, S., Smyth, J.A., McCullough, S.J., Allan, G.M., McNeilly, F, and McQuaid, S. 19886. Confirmation of cause of recent scal deaths. Nature, Lond. 335(6189):404. 
Kennedy, S., Smyth, J.A., Cush, P.F., Duignan, P., Platten, M., McCullough, S.J. and Allan, G.M. 1989. Histopathologic and immunocytochemical studies of distemper in seals. Vet. Pathot. 26:97-103.

Kennedy, S., Di Guardo, G., McConnell, S., Moffett, D. and Agrimi, U. 1993. Histological, histochemical and ultrastructural features of cytoplasmic inclusions in hepatocytes of striped dolphins. J. Comp. Pathol. 109:179-85.

Kjellqvist, S.A., Haug, T, and Øritsland, T. 1995. Changes in age composition, growth and reproductive parameters of the Barents Sea harp seals. Phoca groenlandica. ICES J. Mar. Sci. 52:197-208.

Koeman, J.H.Y., Woustra, A., Peters, W.H.M., de Goeij, J.J.M., Zegers, C. and van Haafen, J.J. 1971. Mercury in the Dutch littoral environment. TNO Nieuws 26:402-9. [In Dutch].

Koski, W.R., Davis, R.A., Miller, G.W. and Withrow, D.E. 1993. Reproduction. pp. 239-74. In: J.J. Burns, J.J. Montague and C.J. Cowles (eds.) Special Publication. No. 2. The Bowhead Whale. 1st. Edn. Society for Marine Mammalogy, Lawrence, Kansas.

Kuiken, T. and García Hartmann, M. 1993. Proceedings of the first European Cetacean Society workshop on cetacean pathology: dissection techniques and tissue sampling. ECS New'sletter 17:1-39.

Lahvis, G.P., Wells, R.S., Casper, D. and Via, C.S. 1993. In-vitro lymphocyte response of bottlenose dolphins (Tursiops truncatus): mitogen-induced proliferation. Mar. Environ. Res. 35(1-2):115-9.

Lahvis, G.P., Wells, R.S., Kuehl, D.W., Stewart, J.L., Rhinehart, H.L. and Via, C.S. 1995. Decreased lymphocyte responses in free-ranging bottlenose dolphins (Tursiops truncatus) are associated with increased concentrations of PCBs and DDT in peripheral blood. Environ. Health Perspect. 103:67-72.

Langston, W.J. 1990. Toxic effects of metals and the incidence of metal pollution in the marine ecosystem. In: R.W. Furness and P.S. Rainbow (eds.) Heavy Metals in the Marine Environment. CRC Press.

Law, R.J. 1994. Collaborative UK Marine Mammal Project: summary of data produced 1988-1992. Fisheries Research Technical Report 97, MAFF, Lowestoft, UK. 42pp.

Lipscomb, T.P., Kennedy, S., Moffett, D. and Ford, B.K. 1994a. Morbilliviral disease in an Atlantic bottlenose dolphin (Tursiops truncatus) from the Gulf of Mexico. J. Wildl. Dis. 30(4):572-6.

Lipscomb, T.P., Schulman, F.Y., Moffett, D. and Kennedy, S. 1994b. Morbilliviral disease in Atlantic bottlenose dolphins (Tursiops truncatus) from the 1987-1988 epizootic. J. Wildl. Dis. 30(4):567-71.

Loganathan, B.G. and Kannan, K. 1994. Global organochlorine contamination trends: An overview. Ambio 23:187-91.

McCarthy, J.F. and Shugart, L.R. 1990. Biomarkers of Environmental Contamination. Lewis, Boca Raton, Florida. 457 pp.

Morse, D.C., Van der Pas, M., Klasson-Wehler, E., De Bie, A.T., Van Bladeren, P.J. and Brouwer, A. 1995. Metabolism and biochemical effects of 3,3',4,4'-tetrachlorobiphenyl in pregnant and fetal rats. Chem.-Biol. Interact 95:41-56.

Murk, A.J., Morse, D.C., Boon, J.P. and Brouwer, A. 1994. In vitro metabolism of $3,3^{\prime}, 4,4^{\prime}$-tetrachlorobiphenyl in relation to ethoxyresorufin- $O$-deethylase activity in liver microsomes of some wildlife species and rat. Eur. J. Pharmacol. 270:253-61.

Nishiwaki, M. 1953. Hermaphroditism in a dolphin (Prodelphinus caeruleo-albus). Sci. Rep. Whales Res. Inst., Tokyo 8:215-8.

Olsson, M., Karlsson, B. and Ahnland, E. 1994. Diseases and environmental contaminants in seals from the Baltic and the Swedish west coast. Sci. Total Environ. 154:217-27.

O'Shea, T.J. and Brownell, R.L. 1994. Organochlorine and metal contaminants in baleen whales - a review and evaluation of conservation implications. Sci. Total Environ. 154(2-3):179-200.

Osterhaus, A.D.M.E. and Vedder, E.J. 1988. Identification of virus causing recent seal deaths. Nature, Lond. 335:20.

Osterhaus, A.D.M.E., Broeders, H.W.J., Groen, J., UytdeHaag, F.G.C.M., Visser, I.K.G., van de Bildt, M.W.G., Orvell, C., Humarev, V.P. and Zorin, V.L. 1989. Different morbilliviruses in European and Siberian seals. Vet. Rec. 125:647-8.

Peakall, D.B. and Walker, C.H. 1994. The role of biomarkers in environmental assessment. Ecotoxicol. Environ. Saf. 3:173-9.

Rawson, A.J., Patton, G.W., Hofmann, S., Pietra, G.G. and Johns, L. 1993. Liver abnormalities associated with chronic mercury accumulation in stranded Atlantic bottlenose dolphins. Ecotoxicol. Environ. Saf. 25(1):41-7.

Ray, S., Dunn, B.P., Payne, J.F., Fancey, L., Helbig, R. and Béland, P. 1991. Aromatic DNA-carcinogen adducts in beluga whales from the Canadian Arctic and Gulf of St. Lawrence. Mar. Pollut. Bull. 22(8):392-6.

Reijnders, P.J.H. and de Ruiter-Dijkman, E.M. 1995. Toxicological and epidemiological significance of pollutants in marine mammals. pp. 575-87. In: A.S. Blix, L. Walløe and Ø. Ulltang (eds.) Whales, Seals, Fish and Man. Elsevier Science BV, Amsterdam. 
Ross, P.S., De Swart, R.L., Reijnders, P.J.H., Loveren, H.V., Vos, J.G. and Osterhaus, A.D.M.E. 1995. Contaminant related suppression of delayed-type hypersensitivity and antibody responses in harbour seals fed herring from the Baltic Sea. Environ. Health Perspect. 103(2):162-7.

Scott, M.D., Wells, R.S. and Irvine, A.B. 1990. A long-term study of bottlenose dolphins on the west coast of Florida. pp. 235-44. In: S. Leatherwood and R.R. Reeves (eds.) The Bottlenose Dolphin. Academic Press, San Diego, CA. 653pp.

Shugart, L.R., Martineau, D. and Béland, P. 1990. Detection and quantification of benzo(a)pyrene adducts in brain and liver tissues of beluga whales (Delphinapterus leucas) from the St. Lawrence and Mackenzie estuaries. pp. 219-23. In: J. Prescott and M. Gauquelin (eds.) Proceedings, International Forum for the Future of the Beluga. Presses Université du Québec, Sillery, Québec. i-xxxii+345pp.

Simmonds, M.P., Johnston, P.A. and French, M.C. 1993. Organochlorine and mercury contamination in UK seals. Vet. Rec. 132:291-5.

Stede, G. and Stede, M. 1990. Orientierende Untersuchungen von Seehundschädeln auf pathologische Knochenveränderungen. pp. 5331-53. In: Zoologische und Ethologische Untersuchungen zum Robbensterben. Institute für Haustierkunde, Kiel, Germany. [In German].

Subramanian, A.N., Tanabe, S., Tatsukawa, R., Saito, S. and Miyazaki, N. 1987. Reduction in the testosterone levels by PCBs and DDE in Dall's porpoises of the northwestern North Pacific. Mar. Pollut. Bull. 18(12):643-6.

Tanabe, S., Iwata, H. and Tatsukawa, R. 1994. Global contamination by persistent organochlorines and their ecotoxicological impact on marine mammals. Sci. Total Environ. 154:163-77.

Thompson, P.M. and Hammond, P.S. 1992. The use of photography to monitor dermal disease in wild bottlenose dolphins (Tursiops truncatus). Ambio 21(2):135-7.

UNEP. 1991. Contaminants and Marine Mammals. Report of the meeting of the Scientific Advisory Committee to the Planning and Coordinating Group of the Marine Mammal Action Plan, Palma 6-8 November 1991. 6pp.

Visser, I.K.G., van Bressem, M.F., de Swart, R.L., van de Bildt, M.W.G., Vos, H.W., van der Heijden, R.W.K., Saliki, J.T., Orvell, C., Kitching, P., Kuiken, T., Barrett, T. and Osterhaus, A.D.M.E. 1993. Characterisation of morbilliviruses isolated from dolphins and porpoises in Europe. J. Gen. Vir. 74:631-41.

Watanabe, S., Shimada, T., Nakamura, S., Nishiyama, N., Yamashita, N., Tanabe, S. and Tatsukawa, R. 1989. Specific profiles of liver microsomal cytochrome P-450 in dolphin and whales. Mar. Emiron. Res. 27:51-65.

Wells, R.S. and Scott, M.D. 1990. Estimating bottlenose dolphin population parameters from individual identification and capture-release techniques. Rep. int. Whal. Commn (special issue 12):407-15.

White, R.D., Hahn, M.E., Lockhart, L.L. and Stegeman, J.J. 1994. Catalytic and immunochemical characterisation of hepatic microsomal cytochromes P450 in beluga whale (Delphinapterus leucas). Toxicol. Appl. Pharmacol. 126:45-57.

Würsig, B. and Jefferson, T.A. 1990. Methods of photo-identification for small cetaceans. Rep. int. Whal. Commn (special issue 12):43-52. 